Neodymium Isotopic Evidence for Early Proterozoic Units in the Watersmeet Gneiss Dome, Northern Michigan

\title{
Temperature-Pressure Estimates of
}

Dynamically Recrystallized Rocks in the Early Proterozoic Mountain Shear Zone, Northeastern Wisconsin

\section{U.S. GEOLOGICAL SURVEY BULLETIN 1904-G, H}


Instructions on ordering publications of the U.S. Geological Survey, along with prices of the last offerings, are given in the current-year issues of the monthly catalog "New Publications of the U.S. Geological Survey." Prices of available U.S. Geological Survey publications released prior to the current year are listed in the most recent annual "Price and Availability List." Publications that are listed in various U.S. Geological Survey catalogs (see back inside cover) but not listed in the most recent annual "Price and Availability List" are no longer available.

Prices of reports released to the open files are given in the listing "U.S. Geological Survey Open-File Reports," updated monthly, which is for sale in microfiche from the U.S. Geological Survey, Books and Open-File Reports Section, Federal Center, Box 25425, Denver, CO 80225. Reports released through the NTIS may be obtained by writing to the National Technical Information Service, U.S. Department of Commerce, Springfield, VA 22161; please include NTIS report number with inquiry.

Order U.S. Geological Survey publications by mail or over the counter from the offices given below.

\section{BY MAIL}

\section{Books}

Professional Papers, Bulletins, Water-Supply Papers, Techniques of Water-Resources Investigations, Circulars, publications of general interest (such as leaflets, pamphlets, booklets), single copies of Earthquakes \& Volcanoes, Preliminary Determination of Epicenters, and some miscellaneous reports, including some of the foregoing series that have gone out of print at the Superintendent of Documents, are obtainable by mail from

\section{U.S. Geological Survey, Books and Open-File Reports Federal Center, Box 25425 Denver, CO 80225}

Subscriptions to periodicals (Earthquakes \& Volcanoes and Preliminary Determination of Epicenters) can be obtained ONLY from the

\section{Superintendent of Documents Government Printing Orfice Washington, D.C. 20402}

(Check or money order must be payable to Superintendent of Documents.)

\section{Maps}

For maps, address mail orders to

$$
\begin{gathered}
\text { U.S. Geological Survey, Map Distribution } \\
\text { Federal Center, Box } 25286 \\
\text { Denver, CO } 80225
\end{gathered}
$$

Residents of Alaska may order maps from

$$
\begin{gathered}
\text { Alaska Distribution Section, U.S. Geological Survey, } \\
\text { New Federal Building - Box } 12 \\
101 \text { Twelfth Ave., Fairbanks, AK } 99701
\end{gathered}
$$

\section{OVER THE COUNTER}

\section{Books}

Books of the U.S. Geological Survey are available over the counter at the following Geological Survey Public Inquiries Offices, all of which are authorized agents of the Superintendent of Documents:

- WASHINGTON, D.C.--Main Interior Bldg., 2600 corridor, 18 th and C Sts., NW.

- DENVER, Colorado-Federal Bldg., Rm. 169, 1961 Stout St.

- LOS ANGELES, California--Federal Bldg., Rm. 7638, 300 N. Los Angeles St.

- MENLO PARK, Callfornia--Bldg. 3 (Stop 533), Rm. 3128, 345 Middlefield Rd.

- RESTON, Virginia--503 National Center, Rm. 1C402, 12201 Sunrise Valley Dr.

- SALT LAKE CITY, Utah--Federal Bldg., Rm. 8105, 125 South State St.

- SAN FRANCISCO, California--Customhouse, Rm. 504, 555 Battery St.

- SPOKANE, Washington--U.S. Courthouse, Rm. 678, West 920 Riverside Ave.

- ANCHORAGE, Alaska--Rm. 101, 4230 University Dr.

- ANCHORAGE, Alaska--Federal Bldg, Rm. E-146, 701 C St.

\section{Maps}

Maps may be purchased over the counter at the U.S. Geological Survey offices where books are sold (all addresses in above list) and at the following Geological Survey offices:

- ROLLA, Missouri--1400 Independence Rd.

- DENVER, Colorado--Map Distribution, Bldg. 810, Federal Center

- FAIRBANKS, Alaska--New Federal Bldg., 101 Twelfth Ave. 


\section{Neodymium Isotopic Evidence for Early Proterozoic Units in the Watersmeet Gneiss Dome, Northern Michigan}

BY KARIN M. BAROVICH, P. JONATHAN PATCHETT, ZELL E. PETERMAN, and P.K. SIMS

\section{Temperature-Pressure Estimates of} Dynamically Recrystallized Rocks in the Early Proterozoic Mountain Shear Zone, Northeastern Wisconsin

BY WARREN C. DAY, P.K. SIMS, and ZELL E. PETERMAN

U.S. GEOLOGICAL SURVEY BULLETIN 1904

CONTRIBUTIONS TO PRECAMBRIAN GEOLOGY OF LAKE SUPERIOR REGION 


\title{
U.S. DEPARTMENT OF THE INTERIOR
}

MANUEL LUJAN, JR., Secretary

\author{
U.S. GEOLOGICAL SURVEY \\ Dallas L. Peck, Director
}

Any use of trade, product, or firm names in this publication is for descriptive purposes only and does not imply endorsement by the U.S. Government.

For sale by the

Books and Open-File Reports Section

U.S. Geological Survey

Federal Center

Box 25425

Denver, CO 80225

\section{Library of Congress Cataloging-in-Publication Data}

Neodymium isotopic evidence for Early Proterozoic units in the Watersmeet Gneiss Dome, northern Michigan / by Karin M. Barovich ... [et al].

Temperature-pressure estimates of dynamically recrystallized rocks in the Early Proterozoic Mountain Shear Zone, northeastern Wisconsin / by Warren C. Day, P.K. Sims, and Zell E. Peterman.

p. $\quad \mathrm{cm}$.- (Contributions to Precambrian geology of Lake Superior region ;

ch. G-H) (U.S. Geological Survey bulletin ; 1904-G-H)

"Chapters $\mathrm{G}$ and $\mathrm{H}$ issued as a single volume and are not available separately."

Includes bibliographical references.

Supt. of Docs. no.: I 19.3:1904-G-H

1. Geology, Stratigraphic-Proterozoic. 2. Geology, StratigraphicArchaean. 3. Gneiss-Michigan. 4. Radioactive dating-Michigan. 5. Geology-Michigan. 6. Rock deformation-Wisconsin. 7. GeologyWisconsin. I. Barovich, Karin M. II. Day, Warren C. III. Sims, P.K. (Paul Kibler), 1918- . IV. Peterman, Zell E . V. Title: Watersmeet Gneiss Dome, northern Michigan. VI. Title: Mountain Shear Zone, northeastern Wisconsin. VII. Series. VIII. Series: U.S. Geological Survey bulletin ; 1904-G-H. 
Chapter G

Neodymium Isotopic Evidence for Early Proterozoic Units in the Watersmeet Gneiss Dome, Northern Michigan

By KARIN M. BAROVICH, P. JONATHAN PATCHETT, ZELL E. PETERMAN, and P.K. SIMS

U.S. GEOLOGICAL SURVEY BULLETIN 1904

CONTRIBUTIONS TO PRECAMBRIAN GEOLOGY OF LAKE SUPERIOR REGION

P.K. SIMS and L.M.H. CARTER, Editors 


\title{
CONTENTS
}

\author{
Abstract $\quad$ G1 \\ Introduction $\mathbf{G 1}$ \\ Geology G3 \\ Geochronology and geochemistry G3 \\ Analytical methods $\mathbf{G 3}$ \\ Results G5 \\ Discussion G6 \\ Conclusions $\quad$ G7 \\ References cited G7
}

\section{FIGURES}

1. Geologic map of the northern part of Watersmeet gneiss dome, northern Michigan G2

2. AFM diagram for rocks from Watersmeet gneiss dome $\mathbf{G 3}$

3. Graph showing $\mathrm{Nd}$ isotopic data for rocks from Watersmeet gneiss dome G5

TABLE

1. Sm-Nd data for rocks from Watersmeet gneiss dome

G4 


\title{
Neodymium Isotopic Evidence for Early Proterozoic Units in the Watersmeet Gneiss Dome, Northern Michigan
}

\author{
By Karin M. Barovich, ${ }^{1}$ P. Jonathan Patchett, ${ }^{1}$ Zell E. Peterman, and P.K. Sims
}

\begin{abstract}
In the Watersmeet gneiss dome, Upper Peninsula of Michigan, neodymium isotopic data for three gneiss units previously thought to be entirely Archean in age demonstrate that one unit, biotite gneiss and schist, must be primarily Early Proterozoic in origin. $\mathrm{T}_{\mathrm{CHUR}}$ (chondrite uniform reservoir) ages for six of the gneiss samples range from 3.72 to $3.54 \mathrm{Ga}$, confirming the Early Archean origin of the majority of the gneisses in the dome. $T_{D M}$ (depleted-mantle) ages for four samples from a biotite gneiss and schist unit from the dome, however, range from 2.37 to $2.25 \mathrm{Ga}$, and $\varepsilon_{\mathrm{Nd}}(1.8)$ values range from -3.1 to -2.3 , indicating a mixture of an Early Proterozoic source with some recycled Archean material. The biotite gneiss and schist unit has uncommonly high samarium and neodymium concentrations relative to the other gneisses in the dome, between 13 and 26 parts per million and 71 and 142 parts per million, respectively. These and other high incompatible element concentrations suggest that the protolith of the Early Proterozoic unit possibly was volcanic, representing quite a strongly chemically differentiated magma. The presence of disseminated fluorite in the Early Proterozoic rocks suggests that they formed in a volatile-rich environment.
\end{abstract}

\section{INTRODUCTION}

Two Archean terranes are recognized in the Lake Superior region: (1) a Late Archean greenstone-granite terrane and (2) an Early to Late Archean gneiss terrane. The gneiss terrane lies south of the greenstone-granite terrane and is separated from it by the Great Lakes tectonic zone

Manuscript approved for publication, September 21, 1990.

${ }^{1}$ Department of Geosciences, University of Arizona, Tucson, AZ 85721.
(GLTZ), a presumed paleosuture of subcontinental length (Sims and others, 1980). The greenstone-granite terrane is the southernmost part of the Superior province, and is termed the Wawa subprovince (Card and Ciesielski, 1986).

The Watersmeet gneiss dome, in the Upper Peninsula of Michigan, is one of several gneiss domes south of the GLTZ (Morey and others, 1982) that are cored by gneiss, migmatite, and amphibolite and are partly overlain by Early Proterozoic metasedimentary and metavolcanic rocks of the Marquette Range Supergroup (Sims, 1990). They owe their origin to Early Proterozoic (Penokean) deformation (Sims and others, 1984). Of the domes that have been studied, the Watersmeet dome formed at a higher pressure $(7 \mathrm{kbar})$ than the others and at temperatures in the range of $600-650^{\circ} \mathrm{C}$ (Attoh and Klasner, 1989). As a consequence, rocks in the core of the Watersmeet dome were metamorphosed to amphibolite facies and were complexly folded and tectonically interleaved and mylonitized during the doming. Sims and others (1984) concluded from the geochronological data available that all the gneisses in the core probably are Archean in age. A subsequent $\mathrm{Sm}-\mathrm{Nd}$ whole-rock isotopic study of representative samples of the gneisses, reported herein, however, has shown that some of the gneisses are Early Proterozoic.

The purpose of this report is to (1) describe the principal types of gneisses in the dome, (2) present the $\mathrm{Sm}-\mathrm{Nd}$ data, and (3) point out the utility of $\mathrm{Nd}$ isotopic work in distinguishing crustal formation ages in highly complex, metamorphosed terranes. Subsequent to recognition of the Early Proterozoic gneisses, two of us (Sims and Peterman) reexamined the field relations, collected additional samples, and studied additional thin sections. Figure 1, revised from the earlier published geologic map (Sims and others, 1984, fig. 2), is based on these new studies combined with the $\mathrm{Nd}$ isotopic data. 


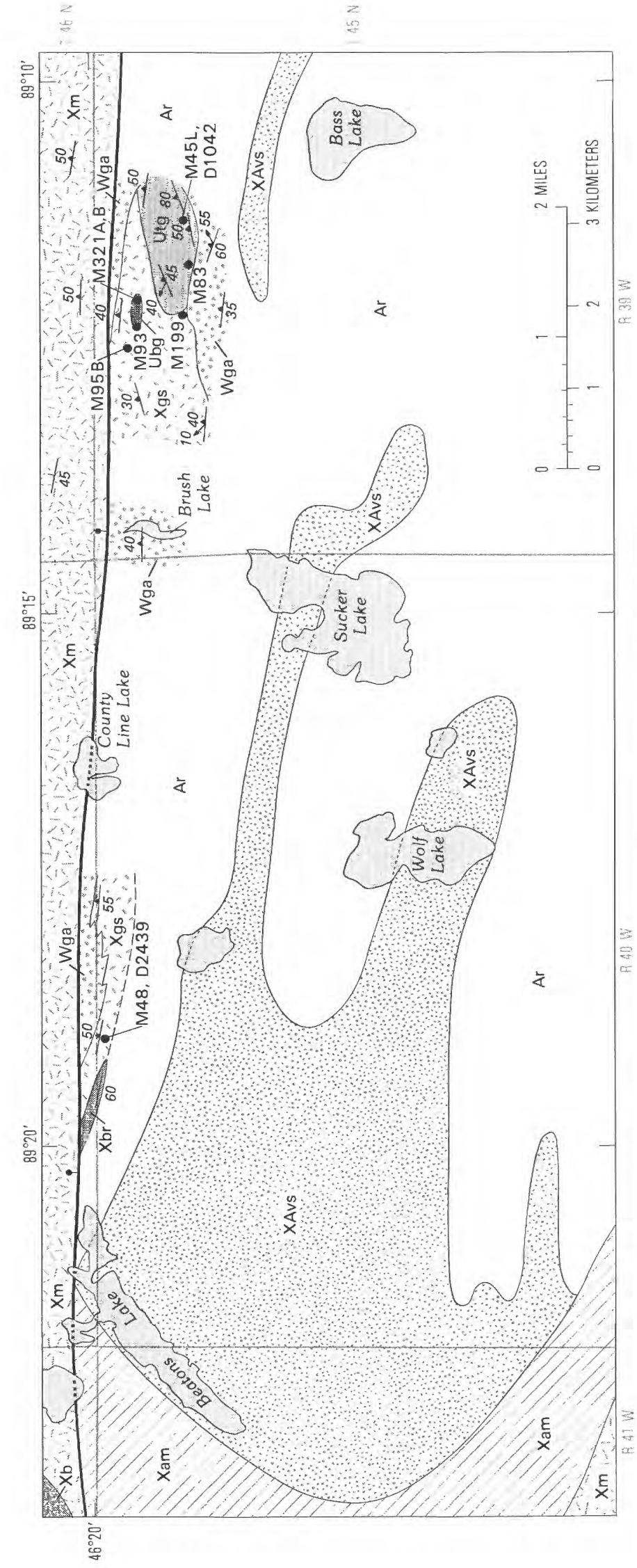

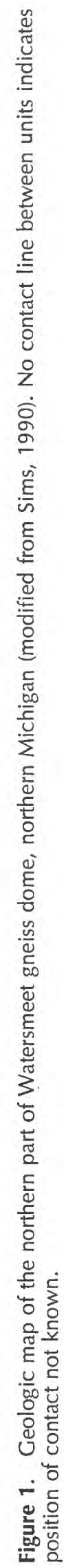




\section{GEOLOGY}

Three major gneiss units were delineated during mapping in the area of the Watersmeet dome (Sims and others, 1984). These units are (1) tonalitic augen gneiss, exposed mainly in the northern part of the dome (fig. 1); (2) a complexly interlayered biotite gneiss succession, which overlies the tonalitic augen gneiss, and (3) an interlayered bimodal amphibolite and biotite gneiss succession, which crops out along the northern part of the dome. Our Sm-Nd study shows that part of the biotite gneiss succession (biotite gneiss and schist) is Early Proterozoic in age.

The tonalitic augen gneiss, the oldest unit (Utg on fig. 1), is a medium-gray, medium- to coarse-grained irregularly layered rock that is invariably mylonitized and recrystallized to finer grain sizes.

The biotite gneiss succession consists of two major rock types, which are intercalated: (1) a medium-grained biotite gneiss (Ubg, fig 1) that varies from massive to layered, on a scale of meters, and (2) a fine- to mediumgrained biotite gneiss and schist (Xgs, fig. 1). Both rock types show multiple deformation and recrystallization, indicated by wide variations in texture and fabric. Some facies of the finer grained gneiss and schist resemble garnetiferous schist of the Early Proterozoic Michigamme Formation (Fritts, 1969). The latter (Xgs, fig. 1) is apparently the dominant unit within the biotite gneiss succession. It differs from the older biotite gneisses in having as much as 6 percent muscovite and as much as 1 percent fluorite.

The third unit (Wga, fig. 1), interlayered amphibolite and biotite gneiss, is a distinctive bimodal volcanic succession that occurs both inside and outside the dome (Sims, 1990).

\section{GEOCHRONOLOGY AND GEOCHEMISTRY}

Peterman and others (1986) determined a U-Pb zircon age of 3,562 $\pm 39 \mathrm{Ma}$ for the tonalitic augen gneiss of the Watersmeet dome. Zircons from one unit of the mediumgrained biotite gneiss within the biotite gneiss succession also plotted on a chord with an upper intercept of $3.56 \mathrm{Ga}$. Rubidium-strontium whole-rock and mineral analyses on these units showed that these systems were reset, and indicated ages of about 1,750 Ma. The interlayered amphibolite and biotite gneiss unit has an age of about 2,640 Ma (Sims and others, 1984).

One sample (M48, fig. 1) of biotite gneiss and schist of the biotite gneiss succession gave a concordant $\mathrm{U}-\mathrm{Pb}$ zircon age of $1,755 \mathrm{Ma}$, which is virtually indistinguishable from the whole-rock and mineral $\mathrm{Rb}-\mathrm{Sr}$ age of $1,750 \pm 90 \mathrm{Ma}$ on the rocks (Sims and others, 1984). Because of the intense

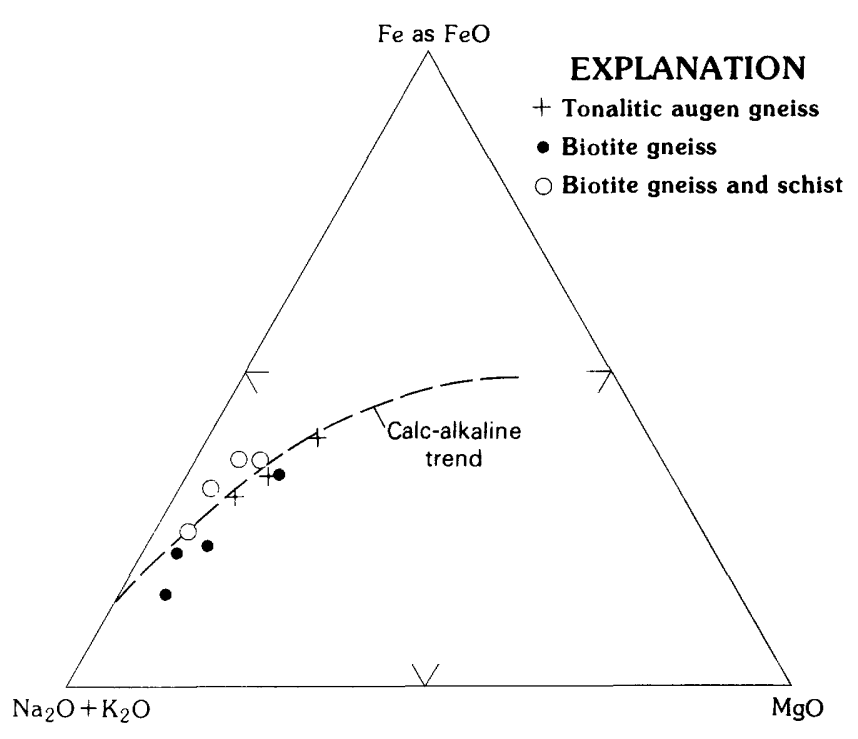

Figure 2. AFM diagram for rocks from Watersmeet gneiss dome. Calc-alkaline trend from Ringwood (1974). Data from Sims and others (1984).

deformation and metamorphism this unit underwent during the Penokean orogeny, Sims and others (1984) concluded that the $\mathrm{Rb}-\mathrm{Sr}$ isochron was a secondary isochron, and interpreted the 1,755 $\mathrm{Ma}$ zircon age as resulting from recrystallized zircon formed during the 1.9-1.7 Ga Penokean orogeny. As discussed herein, however, the analyzed sample (M48) represents a definite Early Proterozoic rock.

Sims and others (1984) presented some major element geochemistry for all the three major rock bodies delineated in the Watersmeet gneiss dome. The range of compositions for samples from the tonalitic augen gneiss and the biotite gneiss succession is narrow, as shown in figure 2; the samples plot as calc-alkaline on this diagram. Accordingly, on the basis of major element geochemistry alone, there is no indication of differences in the age of any of the analyzed rocks of the tonalitic augen gneiss and the biotite gneiss succession.

\section{ANALYTICAL METHODS}

The analytical techniques used for Sm-Nd for crustal rocks are summarized here. Details are given by Patchett and Ruiz (1987).

1. Whole-rock powders were placed in open Teflon bombs with a $\mathrm{HF}-\mathrm{HNO}_{3}$ solution on hot plates to dissolve the major minerals, then sealed in the Teflon bombs with fresh $\mathrm{HF}-\mathrm{HNO}_{3}$ for 7 days.

2. Concentrations and ${ }^{147} \mathrm{Sm}:{ }^{144} \mathrm{Nd}$ ratios were determined with a ${ }^{149} \mathrm{Sm}-{ }^{150} \mathrm{Nd}$ combined spike.

3. Two duplicate analyses are reported (table 1, M45L and D1042). They show that for a rock powder, ${ }^{147} \mathrm{Sm}:{ }^{144} \mathrm{Nd}$ can be reproduced to within 0.5 percent. 
Table 1. Sm-Nd data for rocks from Watersmeet gneiss dome

\begin{tabular}{|c|c|c|c|c|c|c|}
\hline $\begin{array}{c}\text { Sample } \\
\text { No. }\end{array}$ & $\begin{array}{c}\mathrm{Sm} \\
(\mathrm{ppm})\end{array}$ & $\begin{array}{c}\mathrm{Nd} \\
(\mathrm{ppm})\end{array}$ & $\begin{array}{l}{ }^{147} \mathrm{Sm}: \\
{ }^{144} \mathrm{Nd}\end{array}$ & $\begin{array}{l}{ }^{143} \mathrm{Nd:} \\
{ }^{144} \mathrm{Nd}^{*}\end{array}$ & $\begin{array}{c}\mathrm{T}_{\text {CHUR age }} \\
(\mathrm{Ga})\end{array}$ & $\begin{array}{c}T_{\mathrm{DM}} \text { age } \\
\text { (Ga) }\end{array}$ \\
\hline \multicolumn{7}{|c|}{ Tonalitic augen gneiss } \\
\hline M45L & 4.58 & 28.43 & 0.09737 & $0.510216 \pm 9$ & 3.69 & -- \\
\hline M45L & 4.63 & 28.61 & 0.09768 & $0.510223 \pm 9$ & 3.69 & - \\
\hline M83 & 10.92 & 67.17 & 0.09821 & $0.510262 \pm 9$ & 3.65 & -- \\
\hline D1042 & 5.62 & 35.46 & 0.09847 & $0.510251 \pm 13$ & 3.64 & -- \\
\hline D1042 & 5.88 & 36.16 & 0.09833 & $0.510268 \pm 7$ & 3.64 & -- \\
\hline \multicolumn{7}{|c|}{ Biotite gneiss succession } \\
\hline \multicolumn{7}{|c|}{ Biotite gneiss: } \\
\hline M93 & 4.10 & 23.90 & 0.10423 & $0.510387 \pm 13$ & 3.68 & -- \\
\hline M321A & 2.56 & 15.11 & 0.10220 & $0.510315 \pm 7$ & 3.72 & -- \\
\hline M321B & 1.82 & 10.96 & 0.10012 & $0.510376 \pm 10$ & 3.54 & -- \\
\hline \multicolumn{7}{|c|}{ Biotite gneiss and schist: } \\
\hline M95B & 26.33 & 142.27 & 0.11189 & $0.511502 \pm 7$ & 2.04 & 2.30 \\
\hline M199 & 23.77 & 139.63 & 0.10287 & $0.511405 \pm 9$ & 2.00 & 2.25 \\
\hline M48 & 19.70 & 102.91 & 0.11570 & $0.511519 \pm 8$ & 2.10 & 2.37 \\
\hline D2439 & 13.01 & 70.94 & 0.11088 & $0.511508 \pm 3$ & 2.00 & 2.27 \\
\hline
\end{tabular}

* Errors are \pm 2 standard errors of the mean.

\section{SAMPLE DESCRIPTIONS}

Tonalitic augen gneiss $(3.56 \mathrm{Ga})$ :

M45L Medium-grained irregularly layered gneiss. NW11/4SE1/4 sec. 4 ,

T. 45 N., R. 39 W.

M83 Similar to M45L. Coarser layering. NW1/4SW1/4 sec. 4, T. 45 N., R. $39 \mathrm{~W}$.

D1042 Similar to M45L. NW1/4SE1/4 sec. 4, T. 45 N., R. 39 W. (Same locality as M45L.)

Biotite gneiss $(3.56 \mathrm{Ga})$ :

M93 Light-gray fine- to medium-grained layered gneiss. SW1/4NE $1 / 4$ sec. 5 , T. 45 N., R. 39 W.

M321A Medium-grained distinctly layered biotite gneiss. NE $1 / 4 \mathrm{sec} .5$, T. 45 N., R. 39 W.

M321B Similar to M321A, but finer layering. NE1/4 sec. 5, T. 45 N., R. 39 W. (Same locality as M321A.)

Biotite gneiss and schist (Early Proterozoic):

M95B Gray fine-grained biotite gneiss. NW1/4NE1/4 sec. 5, T. 45 N., R. $39 \mathrm{~W}$.

M199 Gray fine-grained biotite schist. NE1/4SE1/4 sec. 5, T. 45 N., R. 39 W.

M48 Strongly cataclasized biotite schist with porphyritic plagioclase. NE $1 / 4$ NW1/4 sec. 4 , T. 45 N., R. 40 W.

D2439 Gray fine-grained biotite schist. NE1/4NW1/4 sec. 4, T. 45 N., R. 40 W. (Same locality as M48.) 


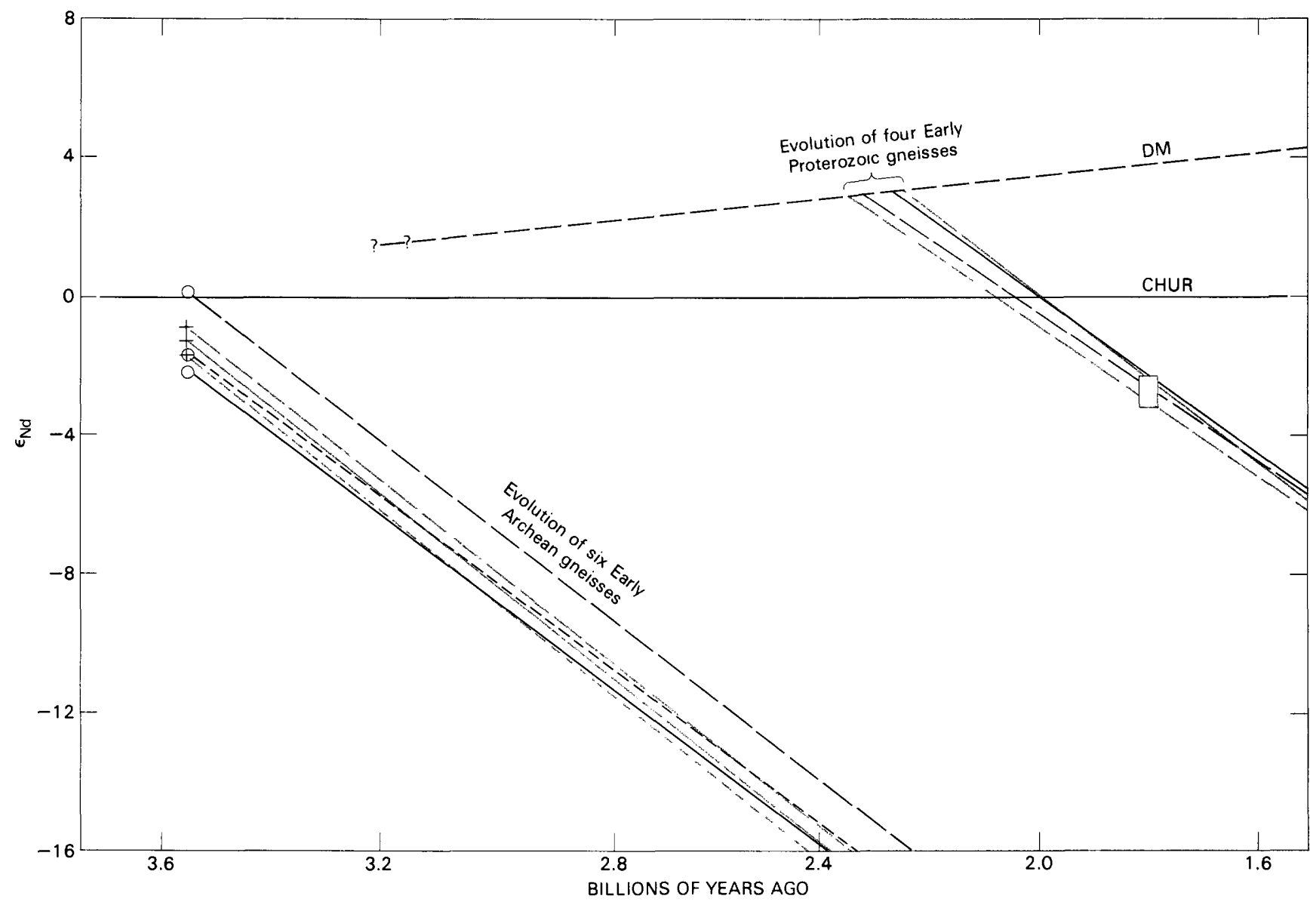

Figure 3. Nd isotopic data for rocks from Watersmeet gneiss dome, plotted as $\varepsilon_{\mathrm{Nd}}$ versus time. CHUR, the chondrite uniform reservoir or bulk Earth isotopic evolution; DM, depleted mantle (DePaolo, 1981). Epsilon, the deviation in parts per ten thousand of the ${ }^{143} \mathrm{Nd}:{ }^{144} \mathrm{Nd}$ ratio of the sample from the chondrite value of the same age. Cross, Early Archean tonalitic augen gneiss; open circle, Early Archean biotite gneiss; open rectangle, range of $\varepsilon_{\mathrm{Nd}}(1.8)$ values for the Early Proterozoic samples.

4. Throughout the period of this study, the La Jolla $\mathrm{Nd}$ standard gave ${ }^{143} \mathrm{Nd}:{ }^{144} \mathrm{Nd}=0.511862 \pm 7$ ( $2 \sigma$ of the mean); 2-sigma errors reported correspond to the last two significant figures.

\section{RESULTS}

We analyzed 10 whole rock samples, 3 from the tonalitic augen gneiss, 3 from the biotite gneiss unit, and 4 from the biotite gneiss and schist unit for $\mathrm{Nd}$ isotopic composition and $\mathrm{Sm}$ and $\mathrm{Nd}$ concentrations. Descriptions and locations of the samples are given in table 1 . Approximate sample localities are shown in figure 1 . Neodymium isotopic data are presented in table 1 , and isotopic evolution, $\varepsilon$ values, and $\mathrm{T}_{\mathrm{CHUR}}$ and $\mathrm{T}_{\mathrm{DM}}$ model ages $^{2}$ are shown in figure $3 . \mathrm{T}_{\mathrm{DM}}$ ages were calculated only

\footnotetext{
${ }^{2}$ Ages derived using chondrite uniform reservoir or bulk Earth isotopic evolution, and depleted-mantle method.
}

for those samples that were determined to have an Early Proterozoic crustal origin. The soundness of the depletedmantle model used (DePaolo, 1981) has been well documented for the Early Proterozoic in this region (Nelson and DePaolo, 1984; Patchett and Arndt, 1986).

The data fall into two groups, according to their model ages. The three tonalitic augen gneiss samples (M45L, M83, and D1042) and the three biotite gneiss samples (M321A, M321B, and M93) form the first group. This group yields Early Archean $\mathrm{T}_{\mathrm{CHUR}}$ ages between 3.72 and $3.54 \mathrm{Ga}$. These model ages are in agreement with the $\mathrm{U}-\mathrm{Pb}$ upper intercept age of $3.56 \mathrm{Ga}$ determined for the tonalitic augen gneiss and one layer of the biotite gneiss unit (Peterman and others, 1980). The evolution through time of these Early Archean gneisses is plotted for reference. At the $\mathrm{U}-\mathrm{Pb}$ crystallization age of $3.56 \mathrm{Ga}, \varepsilon_{\mathrm{Nd}}$ values for these samples range from -2.0 to +0.2 . Sm and $\mathrm{Nd}$ concentrations and ${ }^{147} \mathrm{Sm}:{ }^{144} \mathrm{Nd}$ ratios generally are typical for Early Archean felsic gneisses. (See Taylor and McLennan, 1985, for summary.) The second group includes the biotite gneiss and schist samples (M48, D2439, M199, and M95B). These 
samples have a narrow range of Early Proterozoic $\mathrm{T}_{\mathrm{DM}}$ ages between 2.37 and $2.25 \mathrm{Ga}$ (fig. 3). Because the crystallization ages of these gneisses and schists are unknown, we have plotted their evolution back to their intersection with the depleted mantle curve of DePaolo (1981). Whereas the ${ }^{147} \mathrm{Sm}:{ }^{144} \mathrm{Nd}$ ratios of these samples are representative of typical felsic upper crust, the Sm and Nd concentrations are anomalously high: Sm values range between 13 and $26 \mathrm{ppm}$ and $\mathrm{Nd}$ values between 71 and $142 \mathrm{ppm}$. These values are as much as 4.5 times higher than average upper crustal felsic material.

\section{DISCUSSION}

The $T_{C H U R}$ model ages and $\varepsilon_{N d}$ values for the first group of samples (the tonalitic augen gneiss and the biotite gneiss samples) show that these rocks represent new crustal additions approximately $3.60 \mathrm{Ga}$. Their model ages are also in agreement with $\mathrm{Nd}$ model ages for samples of the tonalitic augen gneiss of the Watersmeet dome analyzed by McCulloch and Wasserburg (1980) and Futa (1981).

The second group of samples has a narrow range of Early Proterozoic $\mathrm{T}_{\mathrm{DM}}$ ages, varying by only 0.12 b.y. (from 2.37 to $2.25 \mathrm{Ga}$ ). It is theoretically possible that this unit is also Early Archean in age, and that its whole-rock system was reset during a later metamorphic episode. That these rocks contain fluorine (in the form of disseminated fluorite) suggests that they may have been exposed to a volatile-rich environment at some point in their history. But if they are Early Archean in age, it would be necessary to invoke largescale REE (rare earth element) mobility to explain their Early Proterozoic model ages. An implausible scenario such as massive flooding of the rocks by extremely REE enriched hydrothermal fluids with an Early Proterozoic isotopic signature during a major metasomatic event would be needed. To achieve the consistent Early Proterozoic model ages, it would be necessary to replace all the original $\mathrm{Sm}$ and $\mathrm{Nd}$ in the rock, and completely delete any Archean isotopic signature. We find this unlikely for two reasons: (1) These rocks show no evidence of the severe and pervasive hydrothermal alteration that would have to result from the circulation of such large volumes of REE-enriched fluids. Megascopically they do not show any evidence of hydrothermal alteration, and microscopically they are unusual only in the presence of fluorite as a common accessory mineral. If the fluorite was introduced by metasomatic fluids, then its occurrence as disseminated grains throughout the unit (not in confined veinlets) would strongly suggest pervasive as opposed to selective hydrothermal alteration. Yet no other minerals record a pervasive alteration event. (2) Given the complicated structural relationships whereby the Early Archean tonalitic augen gneiss and biotite gneiss are interleaved with the biotite gneiss and schist, it is impossible to see how this REE replacement during massive fluid circulation could have been so selective-as long as we assume that the rock types were in their current structural positions relative to each other before the proposed alteration event. We suggest instead that the biotite gneiss and schist unit, represented by the samples with Early Proterozoic model ages, was added to the crust around $1.80 \mathrm{Ga}$, probably during an early phase of the 1.9-1.7 Ga Penokean orogeny, and that it was then structurally interleaved with the Archean gneiss units of the Watersmeet dome during deformation associated with the Penokean event. Barovich and others (1989) have already demonstrated that the Penokean orogeny was a time of major growth of crust from the mantle. The $\approx 2.30 \mathrm{Ga} \mathrm{T}_{\mathrm{DM}}$ ages of the biotite gneiss and schist samples do not correlate with any known igneous or volcanic activity. Instead, we suggest that mixing of two components, depleted mantle and a small percentage of preexisting Archean crustal material, produced the precursors of these rocks, around $1.80 \mathrm{Ga}$. Thus the $T_{\mathrm{DM}}$ model ages of $\approx 2.30 \mathrm{Ga}$ are older than the proposed crystallization age of $1.80 \mathrm{Ga}$, and represent a weighted average of the two components, primitive mantle and recycled Archean crustal material. Existence of a depleted mantle in this area and others in North America has been well documented (Nelson and DePaolo, 1984; Barovich and others, 1989). That some Archean material was incorporated during formation of the gneiss protoliths is reasonable to assume, because the terrane from which these samples were taken contains considerable amounts of Archean basement.

As a result of subsequent field and laboratory work, we have distinguished the Early Proterozoic biotite gneiss and schist from the Early Archean units within the Watersmeet dome. In thin section, the biotite gneiss and schist unit is characterized by 3-6 percent modal muscovite and accessory fluorite. In addition, trace element analyses by K.J. Schulz (unpub. data, 1990) have shown that the rocks are uncommonly enriched in incompatible elements, including $\mathrm{U}$, Th, Ta, $\mathrm{Hf}$, and $\mathrm{Zr}$.

The elevated REE and incompatible element concentrations of these Early Proterozoic rocks are uncommon. The minerals that host the REE budget of the whole rock have not been identified. The presence of fluorite as an accessory mineral disseminated throughout the rocks suggests a volatile-rich environment for the precursor of this unit. Although little experimental evidence exists to gauge the mobility of rare earth and other incompatible elements as fluorine complexes and explain the elevation of incompatible element concentrations in fluorine-rich rocks, much evidence of an empirical nature is available. Alderton and others (1980) attributed REE loss in an altered granite in southwest England to REE complexing by fluorine in the altering fluids. Christiansen and others (1986) cited characteristic enrichments in incompatible lithophile elements in Cenozoic fluorine-rich topaz rhyolites from the Western United States. 


\section{CONCLUSIONS}

Although most of the rock units in the Watersmeet gneiss dome are Early Archean in age, as confirmed by our $\mathrm{Nd}$ isotopic data for the tonalitic augen gneiss and the biotite gneiss, our data have shown that the biotite gneiss and schist unit within the dome is Early Proterozoic. Trace element concentrations, both from this study and unpublished data by K.J. Schulz, show that, geochemically, the Early Proterozoic gneiss and schist unit is quite distinct from the Early Archean gneisses of the Watersmeet dome. Further work is needed to determine the origin of this Early Proterozoic unit and the manner and timing in which these rocks were so complexly interleaved with the Early Archean units of the gneiss dome.

\section{REFERENCES CITED}

Alderton, D.H.M., Pearce, J.A., and Potts, P.J., 1980, Rare earth element mobility during granite alteration-Evidence from southwest England: Earth and Planetary Science Letters, v. 49 , p. 149-165.

Attoh, Kodjopa, and Klasner, J.S., 1989, Tectonic implications of metamorphism and gravity field in the Penokean orogen of northern Michigan: Tectonics, v. 8, p. 911-933.

Barovich, K.M., Patchett, P.J., Peterman, Z.E., and Sims, P.K., $1989, \mathrm{Nd}$ isotopes and the origin of 1.9-1.7 Ga Penokean continental crust of the Lake Superior region: Geological Society of America Bulletin, v. 101, p. 333-338.

Card, K.D., and Ciesielski, Andre, 1986, DNAG No. 1 Subdivision of the Superior Province of the Canadian Shield: Geoscience Canada, v. 13, no. 1, p. 5-13.

Christiansen, E.H., Sheridan, M.F., and Burt, D.M., 1986, The geology and geochemistry of Cenozoic topaz rhyolites from the western United States: Geological Society of America Special Paper 205, $82 \mathrm{p}$.

DePaolo, D.J., 1981, Neodymium isotopes in the Colorado Front Range and crust-mantle evolution in the Proterozoic: Nature, v. 291, p. 193-196.

Fritts, C.E., 1969, Bedrock geologic map of the MareniscoWatersmeet area, Gogebic and Ontonagon Counties, Michigan: U.S. Geological Survey Miscellaneous Geologic Investigations Map I-576, scale 1:48,000.

Futa, Kiyoto, 1981, Sm-Nd systematics of a tonalitic augen gneiss and its constituent minerals from northern Michigan: Geochimica et Cosmochimica Acta, v. 45, p. 1245-1249.

McCulloch, M.T., and Wasserburg, G.J., 1980, Early Archean $\mathrm{Sm}-\mathrm{Nd}$ model ages from a tonalitic gneiss, northern
Michigan, in Morey, G.B., and Hanson, G.N., eds., Selected studies of Archean and lower Proterozoic rocks, northern Canadian Shield: Geological Society of America Special Paper 182, p. 135-138.

Morey, G.B., Sims, P.K., Cannon, W.F., Mudrey, M.G., Jr., and Southwick, D.L., 1982, Geologic map of the Lake Superior region, Minnesota, Wisconsin, and northern Michigan: Minnesota Geological Survey State Map Series 5-13, scale $1: 1,000,000$.

Nelson, B.K., and DePaolo, D.J., 1984, 1,700 Ma greenstone volcanic successions in southwestern North America and isotopic evolution of Proterozoic mantle: Nature, v. 312, p. 143-146.

Patchett, P.J., and Arndt, N.T., 1986, Nd isotopes and tectonics of 1.9-1.7 Ga crustal genesis: Earth and Planetary Science Letters, v. 78, p. 329-338.

Patchett, P.J., and Ruiz, J., 1987, Nd isotopic ages of crust formation and metamorphism in the Precambrian of eastern and southern Mexico: Contributions to Mineralogy and Petrology, v. 87, p. 329-338.

Peterman, Z.E., Zartman, R.E., and Sims, P.K., 1980, Early Archean tonalitic gneiss from northern Michigan, U.S.A., in Morey, G.B., and Hanson, G.N., eds., Selected studies of Archean and lower Proterozoic rocks, southern Canadian Shield: Geological Society America Special Paper 182, p. 125-134.

1986, A protracted Archean history in the Watersmeet gneiss dome, northern Michigan, in Peterman, Z.E., and Schnabel, D.C., eds., Shorter contributions to isotope research: U.S. Geological Survey Bulletin 1622, p. 51-64.

Ringwood, A., 1974, The petrological evolution of island arc systems: Geological Society of London Quarterly Journal, v. 130 , p. $183-204$.

Sims, P.K., 1990, Geologic map of Precambrian rocks, Marenisco, Thayer, and Watersmeet 15-minute quadrangles, Gogebic and Ontonagon Counties, Michigan, and Vilas County, Wisconsin: U.S. Geological Survey Miscellaneous Investigations Series Map I-2093, scale 1:62,500.

Sims, P.K., Card, K.D., Morey, G.B., and Peterman, Z.E., 1980, The Great Lakes tectonic zone-A major crustal structure in central North America: Geological Society of America Bulletin, pt. I, p. 690-698.

Sims, P.K., Peterman, Z.E., Prinz, W.C., and Benedict, F.C., 1984, Geology, geochemistry, and age of Archean and Early Proterozoic rocks in the Marenisco-Watersmeet area, northern Michigan: U.S. Geological Survey Professional Paper 1292-A, $42 \mathrm{p}$.

Taylor, S.R., and McLennan, S.M., 1985, The continental crust-Its composition and evolution: Oxford, England, Blackwell Scientific Publications, 312 p. 
Chapter $\mathrm{H}$

Temperature-Pressure Estimates of Dynamically Recrystallized Rocks in the Early Proterozoic Mountain Shear Zone, Northeastern Wisconsin

By WARREN C. DAY, P.K. SIMS, and ZELL E. PETERMAN 


\title{
CONTENTS
}

\author{
Abstract $\quad$ H1 \\ Introduction $\quad \mathbf{H 1}$ \\ Regional setting H1 \\ Local geologic setting H2 \\ Analytical methods $\mathbf{H} 2$
}

Texture and mineral composition of rocks within the Mountain shear zone $\mathbf{H 2}$ $\mathbf{M}_{2}$ mineralogy and texture $\mathbf{H} \mathbf{2}$

Mineralogic compositions H5

Geobarometry $\mathbf{H 8}$

Geothermometry $\mathbf{H 1 0}$

Conclusions $\mathbf{H} 15$

References cited H16

\section{FIGURES}

1. Regional geologic map of northern Wisconsin and adjacent Michigan $\mathbf{H 3}$

2. Geologic map of the Mountain shear zone, showing sample localities H6

3. Quartz-alkali feldspar-plagioclase ternary diagram of granitoid rocks $\mathbf{H 8}$

4. Photograph showing mosaic texture of quartz and feldspar in a granodiorite (129-85) inside the shear zone $\mathbf{H 8}$

5. Photograph showing a small $\mathbf{M}_{2}$ veinlet formed along margin of primary minerals in a granodiorite (165-85) outside the shear zone $\mathbf{H 9}$

6. Plot of hornblende composition, ${ }^{\mathrm{IV}} \mathrm{Al}$ versus $\mathrm{Na}+\mathrm{K} \quad \mathrm{H} 9$

7. Histogram of An content of plagioclase in rocks from the Mountain shear zone area $\mathbf{H 9}$

8. Plot of plagioclase and alkali feldspar compositions for rocks from the Mountain shear zone H11

9. Photograph showing biotite and $\left(\mathbf{M}_{1}\right)$ garnet in a fine-grained felsic volcanic rock (32-85) outside the shear zone $\mathbf{H 1 5}$

10. Photograph showing biotite and $\left(\mathrm{M}_{2}\right)$ garnet in a granitoid rock (46-85) inside the shear zone H15

11. Garnet-biotite and two-feldspar geothermometry diagram $\mathbf{H 1 6}$

\section{TABLES}

1. Modal mineralogy for rocks of the Mountain area, northeastern Wisconsin $\mathbf{H 4}$

2. Whole-rock geochemistry and normative minerals of rocks from the Mountain shear zone $\mathbf{H 7}$

3. Summary of hornblende microprobe data, and pressure estimates for rocks of the Mountain shear zone $\mathbf{H 1 0}$

4. Summary of mean and standard deviation for feldspar microprobe data and temperature estimates for rocks in the Mountain shear zone area $\mathbf{H 1 2}$

5. Summary microprobe data for garnet and biotite, and temperature estimates for rocks of the Mountain shear zone 


\title{
Temperature-Pressure Estimates of Dynamically Recrystallized Rocks in the Early Proterozoic Mountain Shear Zone, Northeastern Wisconsin
}

\author{
By Warren C. Day, P.K. Sims, and Zell E. Peterman
}

\section{Abstract}

The Mountain shear zone, in northeastern Wisconsin, is a discrete structural belt 2 kilometers wide and 12 kilometers long that transects older $(1,889$ to $1,860 \mathrm{Ma})$ supracrustal and granitoid rocks of the Pembine-Wausau terrane of the Early Proterozoic Wisconsin magmatic terranes. The shear zone is intruded by the 1,812 Ma Hines Quartz Diorite, which provides a minimum age of deformation. Dextral transpressive second-phase $\left(D_{2}\right)$ ductile deformation within the zone reoriented original regional $\left(D_{1}\right)$ deformational fabric and caused dynamic recrystallization, which is recorded in the secondphase $\left(M_{2}\right)$ mineral assemblages. The weak, nearly beddingparallel regional $\left(\mathrm{S}_{1}\right)$ foliation preserved outside the shear zone is overprinted within it by a strong second-phase $\left(S_{2}\right)$ schistosity. Protomylonite and orthomylonite, as well as S-C tectonite, are developed within the shear zone.

Hornblende geobarometry of granitoid rocks and metabasalt indicates that the regional $M_{1}$ pressure of about $4.5 \pm 1$ kilobars was elevated during the second metamorphic episode $\left(\mathrm{M}_{2}\right)$ both within and adjacent to the shear zone to approximately $6.0 \pm 1 \mathrm{kbar}$. Garnet-biotite geothermometry indicates that $\mathrm{M}_{1}$ ranged from $585^{\circ} \mathrm{C}$ to $615^{\circ} \mathrm{C}$, but that $\mathrm{M}_{2}$ equilibrium temperatures may have increased to as much as $654{ }^{\circ} \mathrm{C}$. However, garnet is a rare mineral both outside and inside the shear zone, and hence, the peak $M_{2}$ thermal conditions are only an estimate. Two-feldspar geothermometry indicates that inside the shear zone the feldspars underwent continuous subsolidus reequilibration from peak $\mathrm{M}_{2}$ conditions $\left(574{ }^{\circ} \mathrm{C}\right.$ at 6.0 kilobars) down to very low temperatures $\left(280^{\circ} \mathrm{C}\right.$ at 6.0 kilobars). These data indicate that shear-induced dynamic $\mathrm{M}_{2}$ recrystallization effectively increased pressure and temperature and produced significant alteration in rock and structures during its operation in the Mountain shear zone. Maximum temperature-pressure conditions in the shear zone were followed by cooling to very low temperatures, equivalent to that outside the shear zone.

\section{INTRODUCTION}

This study consisting of field and geochemical analysis documents the mineralogical changes and associated temperatures and pressures attendant to deformation within the Mountain shear zone, northeastern Wisconsin. Early regional $D_{1}$ deformation textures and associated $M_{1}$ metamorphic minerals were overprinted in and adjacent to the shear zone by shear-induced $D_{2}$ fabrics and $M_{2}$ metamorphic mineral assemblages. Geobarometry and geothermometry applied to rocks of similar bulk composition from within and outside the shear zone provide estimates of the temperature and pressure changes produced by the ductile deformation.

\section{Regional Setting}

The Mountain shear zone is a discrete zone of ductile deformation in metavolcanic and granitoid rocks of the Pembine-Wausau terrane, within the Early Proterozoic Penokean orogen (Sims, 1987; Sims and others, 1989). The Penokean orogen lies along the south margin of the Superior province of the Canadian Shield, and in northern Wisconsin and Michigan consists of two lithostratigraphic assemblages (fig. 1). To the north is a continental-margin assemblage of metasedimentary rocks of the Early Proterozoic Marquette Range Supergroup, which overlies an Archean basement. To the south is an assemblage of volcanic and granitoid rocks of the Wisconsin magmatic terranes. The two assemblages are separated by the east-west-trending Niagara fault zone, which is thought to be an Early Proterozoic paleosuture (Sims and others, 1989). The supracrustal rocks of the Mountain shear zone were generated in an island arc and (or) back-arc basin environment in the interval 1,889-1,860 $\mathrm{Ma}$, and were intruded by granitoid rocks in the interval 
between 1,870 and 1,760 Ma. The Hines Quartz Diorite intruded the Mountain shear zone at about 1,812 Ma, thus providing a minimum age for the shear zone. For a more comprehensive regional geologic review the reader is referred to reports by Sims and others $(1989 ; 1990)$ and Sims (1987).

\section{Local Geologic Setting}

The Mountain shear zone is a northeast-trending zone of ductile deformation that is $2 \mathrm{~km}$ wide and exposed for a length of $12 \mathrm{~km}$ (fig. 2). Early Proterozoic metavolcanic rocks of the Waupee Volcanics as well as granodiorite occur along the southeast margin of the shear zone. The eastern part of the shear zone is covered by Quaternary glacial deposits. The shear zone is intruded by the $1.47 \mathrm{Ga}$ Middle Proterozoic anorogenic rocks of the Wolf River batholith along the northern and western periphery (Sims, 1989; fig. 2).

Outside the shear zone, the Waupee Volcanics are massive to thinly bedded, moderately foliated dacitic to rhyolitic tuff and tuff breccia and minor volcanogenic metasedimentary rocks (unit Xwf, fig. 2; tables 1 and 2) containing $\mathbf{M}_{1}$ mineral assemblages. Interbedded with these felsic rocks are minor layers of massive to thinly layered mafic metavolcanic rocks. Along the southeast margin the Waupee Volcanics are olivine-normative metabasaltic rocks with low Mg-numbers (cation ratio of $100 \times \mathrm{Mg}:(\mathrm{Mg}+0.85$ $\left.\mathrm{Fe}_{\text {total }}\right)$ ) that form massive and pillow lava flows and thinly layered mafic tuffs (table 2). Inside the shear zone, the Waupee volcanic rocks are schistose and comprise $M_{2}$ mineral assemblages. In the western part of the shear zone, they consist of interlayered biotite schist, interpreted to have had a felsic volcanic and volcanogenic protolith, and minor amphibole schist. The eastern part of the shear zone is composed dominantly of amphibole schist and quartz diorite schist. The protolith for the amphibole schist was mafic volcanic rocks of the Waupee Volcanics, similar to those outside the shear zone (unit Xwm, fig. 2).

An Early Proterozoic peraluminous granitoid rock intrudes the Waupee Volcanics both outside and inside the shear zone (fig. 2; tables 1 and 2). Outside, the rock is a medium-grained, moderately foliated hornblende granodiorite (fig. 3) with a porphyritic texture resulting from plagioclase and potassium-feldspar phenocrysts; the rock has regional $\mathbf{M}_{1}$ mineral assemblages. Inside the shear zone, the granitoid is a mylonitic biotite-hornblende granodiorite to tonalite gneiss with $\mathbf{M}_{2}$ mineral assemblages. The unit contains porphyroclasts of plagioclase and microcline and lensoid recrystallized quartz aggregates in a fine-grained recrystallized groundmass of plagioclase, alkali feldspar, quartz, and minor biotite and amphibole. Using the terminology of Wise and others (1984), the unit is dominantly a protomylonite with zones of orthomylonite.
The protolith of the unit is the granodiorite exposed outside the shear zone (unit $\mathrm{Xg}$, fig. 2).

\section{Analytical Methods}

Representative samples $(5-10 \mathrm{~kg}$ ) for geochemical analysis (table 2) were selected from outcrops that exhibited the least alteration. The samples were crushed, split, and powdered to less than 100 mesh. All analyses were done in U.S. Geological Survey laboratories in Denver, Colo. Major-oxide sample splits were fused and analyzed by $\mathrm{X}$-ray fluorescence using the method outlined by Taggart and others (1987). Determinations for $\mathrm{FeO}$ followed procedures outlined by Peck (1964), for total $\mathrm{H}_{2} \mathrm{O}$ by Jackson and others (1985), and for $\mathrm{CO}_{2}$ by those reviewed by Jackson and others (1987). Analytical precision and accuracy for the major oxides are less than 3 percent of the reported value. The trace elements $\mathrm{Rb}, \mathrm{Sr}, \mathrm{Y}, \mathrm{Zr}$, and $\mathrm{Nb}$ were determined by $\mathrm{X}$-ray fluorescence using an energydispersive spectrometer with a ${ }^{109} \mathrm{Cd}$ source. Estimated analytical error for this technique is less than 10 percent.

The mineral compositions reported in tables 3-5 were obtained using an analytical research laboratory electron microprobe with six movable spectrometers. Mineral standards chosen were those that are well characterized and had a mean atomic weight similar to that of the unknown. The samples were analyzed with an electron beam current of 10 nanoamps and an accelerator voltage of $15 \mathrm{kev}$. The data were reduced using the MAGIC4 matrix correction program.

\section{TEXTURE AND MINERAL COMPOSITION OF ROCKS WITHIN THE MOUNTAIN SHEAR ZONE}

The rocks of the Mountain shear zone have undergone a regional $M_{1}$ metamorphism, which is overprinted within the shear zone by the shear-induced $M_{2}$ metamorphism. The regional $M_{1}$ metamorphism was of lower amphibolite facies. Outside the shear zone, $\mathbf{M}_{1}$ metamorphism of the felsic volcanic and volcaniclastic rocks produced weakly foliated equigranular, medium-grained biotite-garnet-muscovite schists. Regional $\mathbf{M}_{1}$ metamorphism of the basaltic rocks produced hornblendeplagioclase amphibolite (table 1). Muscovite, epidote, and chlorite are $\mathbf{M}_{1}$ alteration minerals of the granodiorite both inside and outside the shear zone.

\section{$\mathrm{M}_{2}$ Mineralogy and Texture}

Ductile $\mathrm{D}_{2}$ deformation caused dynamic recrystallization $\left(\mathrm{M}_{2}\right)$ both within and adjacent to the shear zone. Adjacent to the shear zone, the felsic volcanic rocks have 

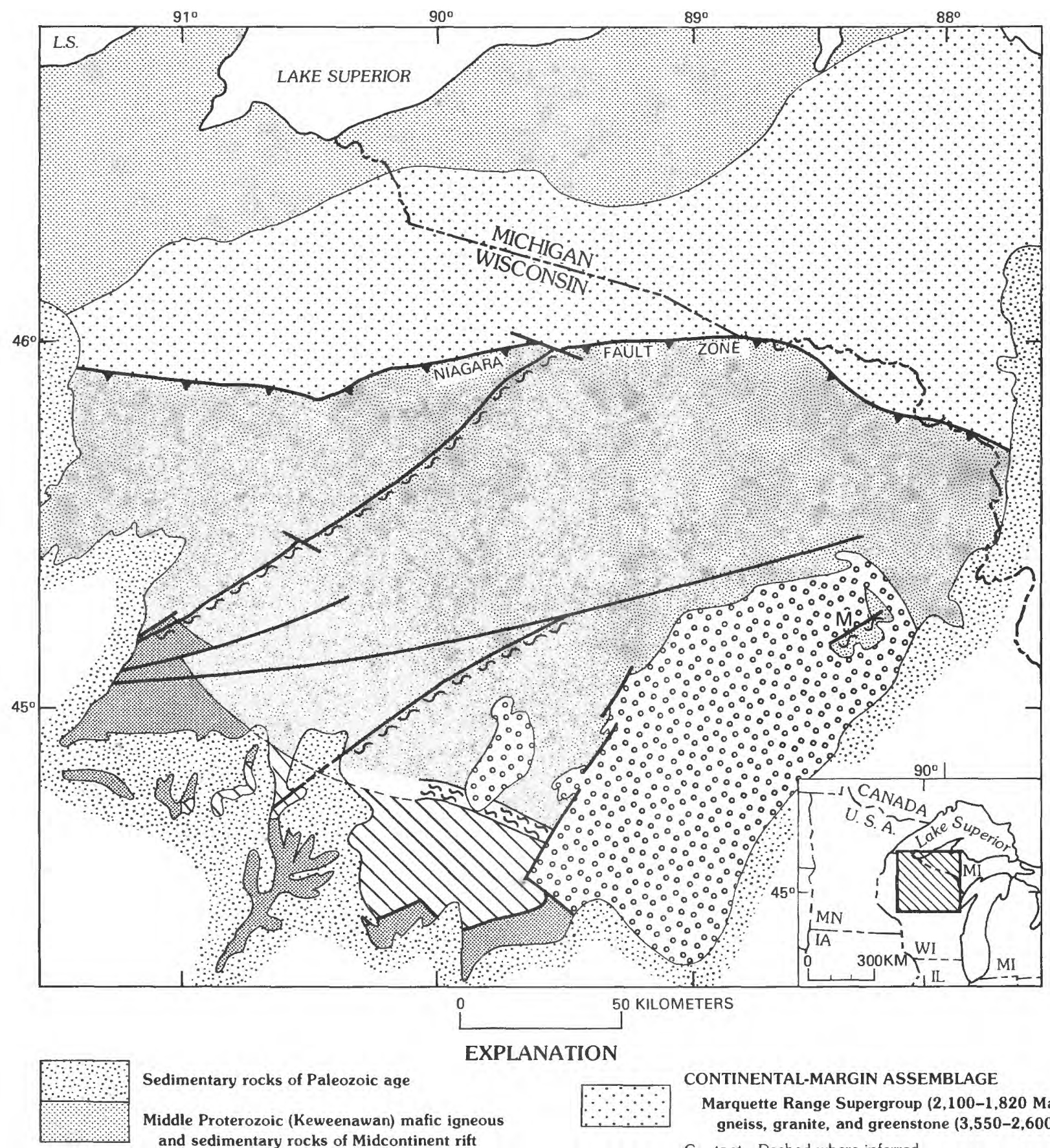

Sedimentary rocks of Paleozoic age

EXPLANATION

Middle Proterozoic (Keweenawan) mafic igneous and sedimentary rocks of Midcontinent rift system $(1,200-1,000 \mathrm{Ma})$

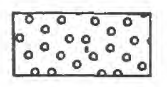

Anorogenic igneous rocks $(1,510-1,470 \mathrm{Ma})$

\section{WISCONSIN MAGMATIC TERRANES}

Metavolcanic and granitoid rocks in PembineWausau terrane $(1,880-1,760 \mathrm{Ma})$

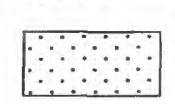

CONTINENTAL-MARGIN ASSEMBLAGE

Marquette Range Supergroup $(2,100-1,820 \mathrm{Ma})$ and gneiss, granite, and greenstone $(3,550-2,600 \mathrm{Ma})$ Contact-Dashed where inferred

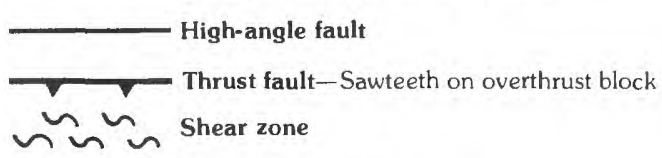

M Mountain shear zone

Metavolcanic and granitoid rocks in Marshfield terrane $(1,890-1,835 \mathrm{Ma})$

Gneiss in Marshfield terrane $(2,800 \mathrm{Ma})$

Figure 1. Regional geology of northern Wisconsin and adjacent Michigan showing relationship of continental-margin assemblage rocks to north and Wisconsin magmatic terranes to south of Niagara fault zone. Study area is near Mountain, Wis. (M). Modified from Sims and others (1990). 
Table 1. Modal mineralogy for rocks of the Mountain area, northeastern Wisconsin

[Values in volume percent. Tr, trace; blank, not determined; amphibole in sample 91-85 is a clinoamphibole, probably cummingtonite]

\begin{tabular}{|c|c|c|c|c|c|c|c|c|c|c|}
\hline \multirow[b]{2}{*}{$\begin{array}{l}\text { Column No. } \\
\text { Sample No. } \\
\text { Rock type }\end{array}$} & \multicolumn{3}{|c|}{ Outside the shear zone } & \multicolumn{7}{|c|}{$\begin{array}{r}\text { Waupee Volcanics and } \\
\text { Inside the }\end{array}$} \\
\hline & $\begin{array}{c}1 \\
23-85 \\
\text { Basalt }\end{array}$ & $\begin{array}{c}2 \\
32-85 \\
\text { Dacite }\end{array}$ & $\begin{array}{c}3 \\
32 \mathrm{~B}-85 \\
\text { Dacite }\end{array}$ & $\begin{array}{c}4 \\
18-85 \\
\text { Basalt }\end{array}$ & $\begin{array}{c}5 \\
164-85 \\
\text { Basalt }\end{array}$ & $\begin{array}{c}6 \\
20-85 \\
\text { Basalt }\end{array}$ & $\begin{array}{c}7 \\
134-85 \\
\text { Quartz } \\
\text { diorite }\end{array}$ & $\begin{array}{c}8 \\
172-85 \\
\text { Quartz } \\
\text { diorite }^{1}\end{array}$ & $\begin{array}{c}9 \\
144-85 \\
\text { Mafic } \\
\text { schist }\end{array}$ & $\begin{array}{c}10 \\
91-85 \\
\text { Mafic } \\
\text { schist }\end{array}$ \\
\hline Plagioclase & 47.2 & 55.2 & 42.0 & 25.0 & 32.0 & 40.8 & 65.6 & 48.8 & 42.0 & 27.5 \\
\hline $\begin{array}{l}\text { Quartz } \\
\text { Microcline }\end{array}$ & 1.0 & $\begin{array}{l}8.0 \\
\operatorname{Tr}\end{array}$ & 10.0 & 1.0 & $\mathrm{Tr}$ & & 9.7 & 22.6 & 41.5 & 31.0 \\
\hline Biotite & & 33.6 & 27.5 & & & 18.6 & 5.6 & 12.2 & 13.0 & 3.0 \\
\hline Hornblende & 51.4 & $\operatorname{Tr}$ & & 68.5 & 64.0 & 35.6 & 18.4 & 15.8 & & 7.0 \\
\hline $\begin{array}{l}\text { Muscovite } \\
\text { Garnet }\end{array}$ & & $\begin{array}{l}\mathrm{Tr} \\
2.0\end{array}$ & $\begin{array}{r}2.5 \\
15.5\end{array}$ & & & & & & $\operatorname{Tr}$ & $\mathrm{Tr}$ \\
\hline Epidote & & & & 3.0 & 2.0 & & & & $\operatorname{Tr}$ & $\operatorname{Tr}$ \\
\hline Sphene & 0.2 & & & 2.0 & $\operatorname{Tr}$ & 4.0 & & & & $\mathrm{Tr}$ \\
\hline Chlorite & & & & $\mathrm{Tr}$ & $\mathrm{Tr}$ & & & & 3.5 & $\mathrm{Tr}$ \\
\hline Calcite & & & & 0.3 & $\operatorname{Tr}$ & & & & $\mathrm{Tr}$ & \\
\hline Magnetite & & & & 0.2 & 2.0 & & & & & \\
\hline Accessory & 0.2 & 1.2 & 2.5 & $\operatorname{Tr}$ & $\operatorname{Tr}$ & 1.0 & 0.7 & 0.6 & $\operatorname{Tr}$ & $\operatorname{Tr}$ \\
\hline
\end{tabular}

\begin{tabular}{|c|c|c|c|c|c|c|c|c|c|c|c|}
\hline \multirow[b]{2}{*}{$\begin{array}{l}\text { Column No. } \\
\text { Sample No. }\end{array}$} & \multicolumn{8}{|c|}{$\begin{array}{c}\text { Granodiorite } \\
\text { Outside the shear zone }\end{array}$} & \multicolumn{3}{|c|}{$\begin{array}{l}\text { Hines Quartz Diorite } \\
\text { Inside the shear zone }\end{array}$} \\
\hline & $\begin{array}{c}22 \\
101-85\end{array}$ & $\begin{array}{c}23 \\
60 \mathrm{~B}-85\end{array}$ & $\begin{array}{c}24 \\
35-85\end{array}$ & $\begin{array}{c}25 \\
112-85\end{array}$ & $\begin{array}{c}26 \\
165-85\end{array}$ & $\begin{array}{c}27 \\
34 \mathrm{~A}-85\end{array}$ & Average & $\begin{array}{l}\text { Standard } \\
\text { deviation }\end{array}$ & $\begin{array}{c}28 \\
147-85\end{array}$ & $\begin{array}{c}29 \\
150-85\end{array}$ & $\begin{array}{c}30 \\
88-85\end{array}$ \\
\hline $\begin{array}{l}\text { Plagioclase } \\
\text { Quartz } \\
\text { Microcline } \\
\text { Biotite } \\
\text { Hornblende } \\
\text { Accessory } \\
\text { Alteration } \\
\quad \text { minerals }\end{array}$ & $\begin{array}{r}42.8 \\
18.2 \\
24.6 \\
8.8 \\
1.8 \\
0.5\end{array}$ & $\begin{array}{r}49.5 \\
15.0 \\
17.5 \\
10.0 \\
7.5 \\
0.5 \\
\\
\mathrm{Tr}\end{array}$ & $\begin{array}{r}40.7 \\
37.6 \\
15.4 \\
5.4 \\
\\
0.8 \\
\\
0.1\end{array}$ & $\begin{array}{r}44.8 \\
14.6 \\
20.6 \\
10.6 \\
7.3 \\
2.1 \\
\\
\operatorname{Tr}\end{array}$ & $\begin{array}{r}51.8 \\
18.2 \\
11.0 \\
9.0 \\
9.8 \\
0.2 \\
\\
T r\end{array}$ & $\begin{array}{r}55.2 \\
21.6 \\
5.7 \\
7.0 \\
9.0 \\
1.5 \\
\\
\operatorname{Tr}\end{array}$ & $\begin{array}{r}47.5 \\
20.9 \\
15.8 \\
8.5 \\
7.1 \\
0.9 \\
\\
0.6\end{array}$ & $\begin{array}{l}5.1 \\
7.8 \\
6.2 \\
1.8 \\
2.8 \\
0.7 \\
\\
1.2\end{array}$ & $\begin{array}{r}47.7 \\
32.6 \\
\\
12.4 \\
6.3 \\
0.9 \\
\\
0.1\end{array}$ & $\begin{array}{r}54.2 \\
2.0 \\
\\
0.9 \\
241.7 \\
1.2\end{array}$ & $\begin{array}{r}41.0 \\
37.3 \\
10.0 \\
8.5 \\
2.5 \\
\mathrm{Tr}\end{array}$ \\
\hline
\end{tabular}

${ }^{1}$ Unit Xwg.

${ }^{2}$ Includes relicts of clinopyroxene.

minor fine-grained intercrystalline $\mathrm{M}_{2}$ mineral phases. Phenocrysts of feldspar and quartz locally have interlocking sutured grain boundaries. The interstitial fine-grained minerals (quartz, feldspar, mica, and opaque minerals) are randomly distributed around the margins of the larger phenocrysts. The felsic volcanic rocks inside the shear zone are strongly foliated and medium grained with ubiquitous fine-grained granular intercrystalline $\mathrm{M}_{2}$ minerals. The primary medium-grained quartz and feldspar crystals form a well-developed mosaic with distinct interlocking sutured crystal boundaries. The intercrystalline $\mathrm{M}_{2}$ mineral matrix forms an interconnected groundmass of fine-grained equigranular "bleb-shaped" quartz, feldspar, mica, and opaque minerals that defines the strong foliation.

Similar textural variations are observed in the mafic volcanic rocks. Outside the shear zone the unit (Xwm, fig. 2) has a weak foliation $\left(S_{1}\right)$, with medium- to coarsegrained plagioclase phenocrysts within fine-grained hornblende aggregates. Fine-grained, granular $\mathrm{M}_{2}$ mineral phases (hornblende, feldspar, and minor quartz) form along the interstices of the $M_{1}$ mineral grain boundaries with no preferred orientation. Inside the shear zone, the foliation within the mafic volcanic rocks (units Xwa and Xwi) is intense, and is defined by a matrix of interlocking elongated fine-grained hornblende crystals and quartz-feldspar blebs and stringers (fig. 4). Both inside and outside the shear zone, the plagioclase phenocrysts are commonly altered to sericite, which is thought to be an $M_{1}$ phase. However, inside the shear zone the fine-grained $\mathbf{M}_{2}$ plagioclase essentially lacks sericite alteration.

Crystal-plastic $\left(D_{2}\right)$ deformation of the granitoid rocks (unit Xgn, fig. 2) within the shear zone has caused $M_{2}$ recrystallization of the coarse-grained quartz crystals, producing large (centimeter-scale) multicrystalline quartz stringers in which the individual crystals have sutured boundaries. The crystal boundaries of the coarse-grained phenocrysts of plagioclase and potassium feldspar differ in being more angular and less recrystallized than the quartz. Biotite is generally restricted to the fine-grained interstitial $\mathrm{M}_{2}$ material. Small 50-150 micrometer-sized blebs of fresh $\mathrm{M}_{2}$ plagioclase and quartz occur within the primary plagioclase phenocrysts (fig. 4). 


\begin{tabular}{|c|c|c|c|c|c|c|c|c|c|c|}
\hline \multicolumn{11}{|c|}{$\begin{array}{l}\text { associated quartz diorite } \\
\text { shear zone }\end{array}$} \\
\hline $\begin{array}{l}11 \\
13-85 \\
\text { Dacite }\end{array}$ & $\begin{array}{c}12 \\
199-85 \\
\text { Dacite }\end{array}$ & $\begin{array}{c}13 \\
76-85 \\
\text { Dacite }\end{array}$ & $\begin{array}{c}14 \\
141-1-85 \\
\text { Dacite }\end{array}$ & $\begin{array}{c}15 \\
167-85 \\
\text { Dacite }\end{array}$ & $\begin{array}{c}16 \\
168-85 \\
\text { Dacite }\end{array}$ & $\begin{array}{c}17 \\
170-85 \\
\text { Dacite }\end{array}$ & $\begin{array}{c}18 \\
18-85 \\
\text { Dacite }\end{array}$ & $\begin{array}{c}19 \\
64-85 \\
\text { Rhyolite }\end{array}$ & $\begin{array}{c}20 \\
173-85 \\
\text { Rhyolite }\end{array}$ & $\begin{array}{c}21 \\
79-85 \\
\text { Rhyolite }\end{array}$ \\
\hline 50.8 & 49.1 & 53.3 & 42.0 & 31.0 & 50.5 & 40.0 & 57.7 & 50.5 & 51.5 & 46.7 \\
\hline 41.2 & 3.5 & 37.3 & 41.5 & 29.0 & 37.5 & 21.5 & 30.7 & 38.7 & 22.5 & 23.6 \\
\hline 2.0 & 31.5 & 0.6 & 2.1 & & & & & 8.3 & 10.0 & 21.7 \\
\hline \multirow[t]{2}{*}{4.9} & & 5.8 & 13.0 & 28.0 & 11.5 & 37.0 & 10.7 & 1.8 & 15.0 & 7.2 \\
\hline & $\begin{array}{l}2.4 \\
0.1\end{array}$ & $\mathrm{Tr}$ & $\mathrm{Tr}$ & 5.0 & $\mathrm{Tr}$ & & & 0.3 & $\mathrm{Tr}$ & 0.8 \\
\hline 0.8 & 44.2 & $\begin{array}{l}0.5 \\
\mathrm{Tr}\end{array}$ & $\operatorname{Tr}$ & $\begin{array}{c}\operatorname{Tr} \\
1.0\end{array}$ & $\begin{array}{c}\mathrm{Tr} \\
0.3\end{array}$ & $\begin{array}{l}\operatorname{Tr} \\
1.0\end{array}$ & & 0.2 & $\begin{array}{l}\operatorname{Tr} \\
\operatorname{Tr}\end{array}$ & \\
\hline $\mathrm{Tr}$ & & & 3.5 & & $\mathrm{Tr}$ & $\mathrm{Tr}$ & & & $\mathrm{Tr}$ & \\
\hline $\mathrm{Tr}$ & 0.1 & $\mathrm{Tr}$ & $\mathrm{Tr}$ & $\mathrm{Tr}$ & $\mathrm{Tr}$ & $\mathrm{Tr}$ & & $\mathrm{Tr}$ & & \\
\hline $\mathrm{Tr}$ & $\mathrm{Tr}$ & 1.0 & & 6.0 & $\mathrm{Tr}$ & $\mathrm{Tr}$ & & $\mathrm{Tr}$ & & $\mathrm{Tr}$ \\
\hline 0.2 & 0.0 & $\mathrm{Tr}$ & $\operatorname{Tr}$ & & 0.2 & 0.5 & 0.9 & 0.2 & $\mathrm{Tr}$ & $\mathrm{Tr}$ \\
\hline
\end{tabular}

\begin{tabular}{|c|c|c|c|c|c|c|c|c|c|c|c|c|}
\hline \multicolumn{13}{|c|}{$\begin{array}{l}\text { Granodiorite gneiss } \\
\text { Inside the shear zone }\end{array}$} \\
\hline $\begin{array}{c}31 \\
39-85\end{array}$ & $\begin{array}{c}32 \\
46-85\end{array}$ & $\begin{array}{c}33 \\
50-85\end{array}$ & $\begin{array}{c}34 \\
129 A-85\end{array}$ & $\begin{array}{c}35 \\
129 B-85\end{array}$ & $\begin{array}{c}36 \\
130 A-85\end{array}$ & $\begin{array}{c}37 \\
130 B-85\end{array}$ & $\begin{array}{c}38 \\
55-85\end{array}$ & $\begin{array}{c}39 \\
40 A-85\end{array}$ & $\begin{array}{c}40 \\
45 B-85\end{array}$ & $\begin{array}{c}41 \\
44-85\end{array}$ & Average & $\begin{array}{l}\text { Standard } \\
\text { deviation }\end{array}$ \\
\hline 44.2 & 49.4 & 48.2 & 29.5 & 54.0 & 51.0 & 47.0 & 46.7 & 46.1 & 44.4 & 48.4 & 46.3 & 6.0 \\
\hline 39.0 & 41.2 & 40.4 & 37.1 & 32.2 & 35.3 & 37.0 & 38.3 & 34.4 & 30.5 & 36.1 & 36.5 & 3.1 \\
\hline 10.6 & & 1.5 & 30.9 & 1.0 & 5.0 & 8.0 & 9.4 & 1.3 & 19.0 & 8.7 & 9.5 & 8.8 \\
\hline 6.0 & 8.4 & 8.4 & 1.1 & 11.0 & 8.2 & 6.5 & 3.4 & 15.0 & 5.4 & 6.5 & 7.3 & 3.5 \\
\hline & & & & 1.0 & & & 1.0 & 0.7 & & & 0.9 & 0.1 \\
\hline $\mathrm{Tr}$ & 0.7 & 1.0 & 0.4 & 0.7 & 0.4 & 1.0 & $\mathrm{Tr}$ & 0.5 & $\mathrm{Tr}$ & $\mathrm{Tr}$ & 0.4 & 0.4 \\
\hline 0.2 & 0.3 & 0.5 & 1.0 & 0.1 & 0.1 & 0.5 & 1.2 & 2.0 & 0.7 & 0.3 & 0.6 & 0.6 \\
\hline
\end{tabular}

Minerals produced by $\mathrm{M}_{2}$ are also developed (although in less abundance) outside the shear zone, indicating that the $\mathrm{D}_{2}$ deformation was not restricted to the shear zone itself. Small $\mathrm{M}_{2}$ blebs of quartz and feldspar are present locally in the granitoid rocks, and thin veinlets $(0.1$ $\mathrm{mm}$ to $0.5 \mathrm{~cm}$ ) of fine-grained, comminuted quartz and feldspar occur along the margins of the primary minerals (fig. 5).

Mylonitic fabric, similar to the type II S-C mylonite fabric of Lister and Snoke (1984), is developed within the granitoid rocks inside the shear zone. The matrix material is oriented parallel to the dominant foliation and represents zones of high-strain (C-surface). Fine-grained mica within the matrix material is commonly oriented at an acute angle of $20^{\circ}-40^{\circ}$ to the dominant foliation, forming a secondary foliation (S-surface) that is compatible with a dextral sense of shearing. Locally, muscovite and (or) biotite "fish," common in S-C mylonites, are developed in the interstitial $\mathrm{M}_{2}$ material and indicate a dextral sense of shear. Sims and others (1990) have described both the regional and local effects of the $D_{1}$ and $D_{2}$ deformation events.

\section{Mineralogic Compositions}

Recrystallization $\left(M_{2}\right)$ resulting from the $D_{2}$ deformation within the Mountain shear zone produced distinct changes in mineral compositions. The hornblende composition changed slightly as a result of reequilibration. Figure 6 shows the microprobe data (table 3 ) for hornblende from basaltic and granodioritic rocks from the study area. In general, in the same sample the early $M_{1}$ hornblende is slightly lower in ${ }^{\mathrm{IV}} \mathrm{Al}$ and $\mathrm{Na}+\mathrm{K}$ abundances than the $\mathrm{M}_{2}$ hornblende. The lower calculated ${ }^{\mathrm{IV}} \mathrm{Al}$ content for the $\mathrm{M}_{1}$ hornblende is a result of relatively higher silicon content; however, the $\mathrm{M}_{1}$ hornblende also has lower total aluminum content.

The plagioclase composition of rocks within the shear zone changed dramatically as a result of $\mathrm{M}_{2}$ dynamic recrystallization. In general, plagioclase became more 

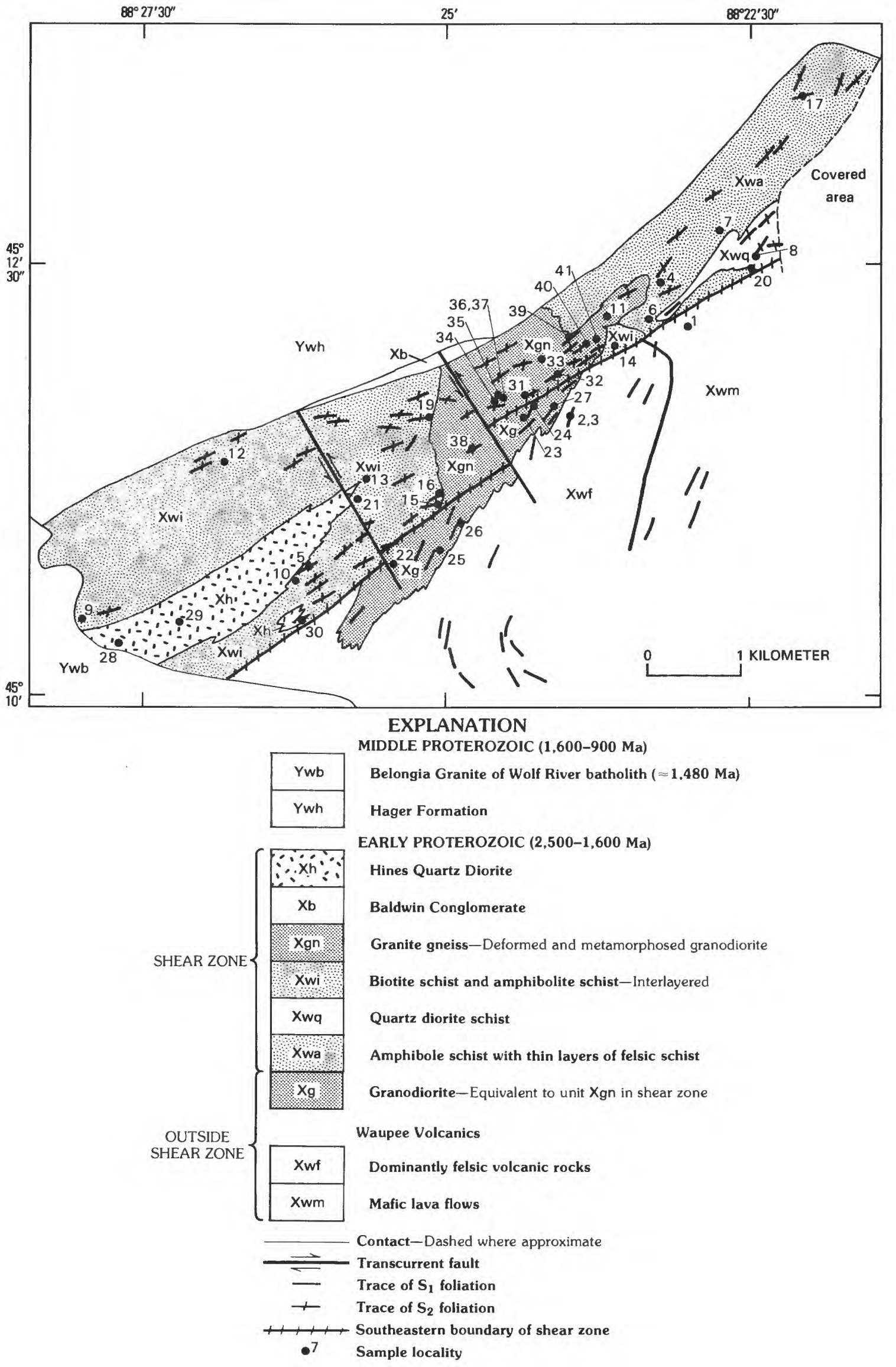
Table 2. Whole-rock geochemistry and normative minerals of rocks from the Mountain shear zone, northeastern Wisconsin

[Major oxide analyses by J. Taggart, A.J. Bartel, and K. Stewart; $\mathrm{FeO}, \mathrm{H}_{2} \mathrm{O}$, and $\mathrm{CO}_{2}$ by R. Brandt and S. Root; minor elements $\mathrm{Rb}$ and $\mathrm{Sr}$ by isotope dilution; chemistry by $\mathrm{K}$. Futa; mass spectrometry by $\mathrm{K}$. Barovich and $\mathrm{T}$. Ball; $\mathrm{Y}$, $\mathrm{Zr}$, and $\mathrm{Nb}(\mathrm{EOXRF})$ by $\mathrm{K}$. Barovich; $\mathrm{Mg}$-number $=\mathrm{Mg} \times 100 /\left(\mathrm{Mg}+\mathrm{Fe}^{+2}\right), \mathrm{Fe}^{+2}$ calculated as $0.85 \times \mathrm{Fe}$ total. $\mathrm{A}: \mathrm{KNC}=\mathrm{Al}_{2} \mathrm{O}_{3} /\left(\mathrm{K}_{2} \mathrm{O}+\mathrm{Na}_{2} \mathrm{O}+\mathrm{CaO}\right)$, molar ratio. Blank, not determined]

\begin{tabular}{|c|c|c|c|c|c|c|c|c|c|}
\hline \multirow{5}{*}{$\begin{array}{l}\text { Column No............. } \\
\text { Sample No.............. }\end{array}$} & \multicolumn{9}{|c|}{ Relation to shear zone } \\
\hline & \multirow{2}{*}{$\frac{\text { Outside }}{1}$} & \multicolumn{2}{|c|}{ Inside } & \multicolumn{2}{|c|}{ Outside } & \multicolumn{4}{|c|}{ Inside } \\
\hline & & 2 & 3 & 4 & 5 & 6 & 7 & 8 & 9 \\
\hline & $23-85$ & $20-85$ & $153-85$ & $27-85$ & $35-85$ & $39-85$ & $130-85$ & $129-85$ & $150-85$ \\
\hline & Basalt & Basalt & Dacite & Rhyolite & $\begin{array}{l}\text { Grano- } \\
\text { diorite }\end{array}$ & $\begin{array}{l}\text { Granite } \\
\text { gneiss }\end{array}$ & $\begin{array}{l}\text { Granite } \\
\text { gneiss }\end{array}$ & $\begin{array}{l}\text { Granite } \\
\text { gneiss }\end{array}$ & $\begin{array}{l}\text { Hines } \\
\text { Quartz } \\
\text { Diorite } \\
\end{array}$ \\
\hline \multicolumn{10}{|c|}{ Major oxides, in weight percent } \\
\hline $\mathrm{SiO}_{2} \ldots \ldots \ldots \ldots \ldots$ & 49.0 & 51.8 & 63.1 & 72.4 & 69.3 & 72.7 & 73.2 & 75.6 & 50.1 \\
\hline $\mathrm{Al}_{2} \overline{\mathrm{O}}_{3} \ldots \ldots \ldots \ldots$ & 18.9 & 17.70 & 17.40 & 14.50 & 14.20 & 13.20 & 13.00 & 12.40 & 19.00 \\
\hline $\mathrm{Fe}_{2} \mathrm{O}_{3} \ldots \ldots \ldots \ldots$ & 2.00 & 2.69 & 0.21 & 0.31 & 0.98 & 0.89 & 0.83 & 0.61 & 0.90 \\
\hline $\mathrm{FeO}$ & 9.54 & 7.30 & 2.89 & 2.19 & 3.14 & 3.18 & 3.10 & 1.52 & 10.80 \\
\hline MgO....................... & 3.54 & 4.77 & 1.64 & 1.69 & 1.00 & 0.50 & 0.55 & 0.22 & 4.57 \\
\hline $\mathrm{CaO}$ & 10.9 & 7.35 & 7.52 & 2.19 & 1.47 & 2.22 & 2.21 & 0.41 & 9.68 \\
\hline $\mathrm{Na}_{2} \mathrm{O}$ & 3.40 & 3.29 & 2.68 & 3.44 & 2.79 & 3.60 & 3.62 & 2.39 & 2.64 \\
\hline $\mathrm{K}_{2} \mathrm{O} \ldots \ldots \ldots \ldots \ldots \ldots$ & 1.09 & 2.28 & 2.97 & 1.33 & 5.52 & 2.50 & 2.34 & 6.48 & 0.64 \\
\hline $\mathrm{TiO}_{2} \ldots \ldots \ldots \ldots$ & 0.66 & 0.73 & 0.65 & 0.29 & 0.23 & 0.19 & 0.18 & 0.02 & 0.70 \\
\hline $\mathrm{P}_{2} \mathrm{O}_{5} \ldots \ldots \ldots \ldots \ldots \ldots$ & 0.1 & 0.25 & 0.23 & 0.05 & 0.09 & $<0.05$ & $<0.05$ & $<0.05$ & 0.17 \\
\hline 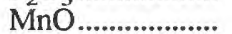 & 0.16 & 0.16 & 0.05 & $<0.02$ & 0.04 & 0.05 & 0.04 & $<0.02$ & 0.19 \\
\hline $\mathrm{H}_{2} \mathrm{O}+\ldots \ldots \ldots \ldots \ldots$ & 1.28 & 1.48 & 0.40 & 1.15 & 0.68 & 0.58 & 0.45 & 0.29 & 0.99 \\
\hline $\mathrm{H}_{2} \mathrm{O}-\ldots \ldots \ldots \ldots \ldots$ & $<0.01$ & 0.04 & 0.02 & 0.02 & $<0.01$ & 0.04 & 0.03 & 0.06 & 0.02 \\
\hline $\mathrm{CO}_{2} \ldots \ldots \ldots \ldots \ldots \ldots$ & 0.19 & 0.03 & $<0.01$ & $<0.01$ & 0.04 & 0.15 & 0.09 & 0.02 & 0.05 \\
\hline Total.... & 100.8 & 99.9 & 99.8 & 99.6 & 99.5 & 99.9 & 99.7 & 100.1 & 100.5 \\
\hline Mg-number....... & 22.10 & 30.86 & 32.67 & 38.43 & 18.41 & 10.25 & 11.49 & 8.80 & 26.35 \\
\hline A:KNC............. & 0.71 & 0.83 & 0.82 & 1.31 & 1.07 & 1.04 & 1.04 & 1.06 & 0.84 \\
\hline \multicolumn{10}{|c|}{ Trace elements, in parts per million } \\
\hline $\mathrm{Rb}$ & 17 & 48 & 35 & 22 & 70 & 47 & 48 & 148 & 14 \\
\hline Sr............................. & 299 & 555 & 208 & 168 & 431 & 175 & 195 & 54 & 346 \\
\hline Y & 12 & 21 & 15 & 22 & 8 & 27 & 18 & 22 & 9 \\
\hline $\mathrm{Zr} \ldots \ldots \ldots \ldots \ldots \ldots$ & 35 & 92 & 91 & 165 & 115 & 93 & 97 & 42 & 27 \\
\hline $\mathrm{Nb}$ & 2 & 9 & 7 & 8 & 2 & 6 & 4 & 7 & 1 \\
\hline $\mathrm{K}: \mathrm{Rb} \ldots \ldots \ldots \ldots \ldots \ldots$ & 541 & 396 & 711 & 511 & 658 & 440 & 402 & 363 & 377 \\
\hline \multicolumn{10}{|c|}{ Normative minerals of rocks } \\
\hline Quartz ................. & & & 18.37 & 38.90 & 25.68 & 35.07 & 35.95 & 34.81 & \\
\hline Corundum ........... & & & & 3.58 & 1.28 & 1.00 & 0.83 & 0.87 & \\
\hline Orthoclase.......... & 6.39 & 13.49 & 17.59 & 7.89 & 32.79 & 14.80 & 13.87 & 38.26 & 20.20 \\
\hline Anorthite............ & 32.84 & 26.83 & 26.74 & 10.52 & 6.49 & 9.75 & 10.10 & 1.58 & \\
\hline Nepheline............ & 1.77 & & & & & & & & \\
\hline Wollastonite...... & 7.93 & 3.28 & 3.79 & & & & & & \\
\hline Enstatite ............. & 2.98 & 9.64 & 4.09 & 4.23 & 2.50 & 1.25 & 1.37 & 0.55 & 9.62 \\
\hline Ferrosilite............ & 5.09 & 8.34 & 4.16 & 3.34 & 4.68 & 4.89 & 4.80 & 2.30 & 15.40 \\
\hline Fosterite .............. & 4.05 & 1.58 & & & & & & & 1.19 \\
\hline Fayalite ................ & 7.62 & 1.51 & & & & & & & 2.11 \\
\hline Magnetite........... & 2.88 & 3.91 & 0.31 & 0.45 & 1.43 & 1.29 & 1.21 & 0.88 & 1.30 \\
\hline Ilmenite .............. & 1.24 & 1.39 & 1.23 & 0.55 & 0.44 & 0.36 & 0.34 & 0.04 & 1.32 \\
\hline Apatite ................... & 0.24 & 0.60 & 0.55 & 0.12 & 0.21 & 0.12 & 0.12 & 0.12 & 0.40 \\
\hline Calcite..................... & 0.43 & 0.07 & 0.02 & 0.02 & 0.09 & 0.34 & 0.21 & 0.05 & 0.11 \\
\hline Magnesite............ & 2.14 & 2.88 & 0.99 & 1.02 & 0.60 & 0.30 & 0.33 & 0.13 & 2.76 \\
\hline
\end{tabular}

Figure 2 (facing page). Geology of the Mountain shear zone, northeastern Wisconsin, showing sample localities. Numbers refer to column numbers in tables 1 and 2. Modified from Sims and others (1990). albitic for rocks of equivalent composition (table 4). Plotted in figure 7 are the combined core and rim analyses for plagioclase for the various rock compositions. A significant shift to more albitic plagioclase compositions occurred in each rock type. The plagioclase composition in the felsic 


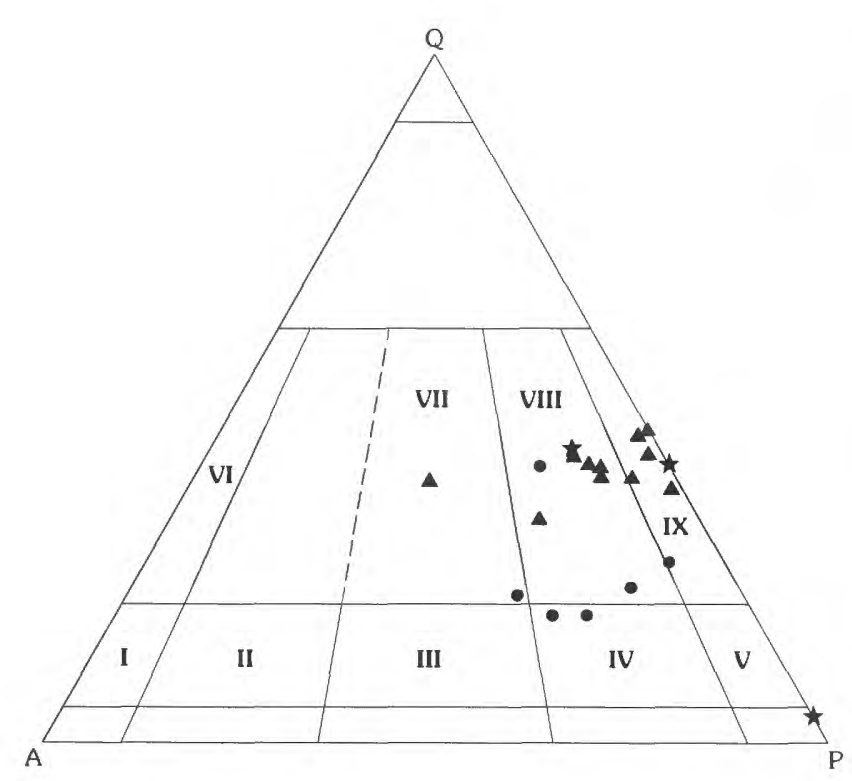

Figure 3. Quartz-alkali feldspar-plagioclase diagram for granodiorite outside the shear zone (dots), granodioritic gneiss inside the shear zone (triangles), and the Hines Quartz Diorite (stars), Mountain area, northeastern Wisconsin. Fields for diagram: I, quartz alkali syenite; II, quartz syenite; III, quartz monzonite; IV, quartz monzodiorite; V, quartz diorite; VI, alkali granite; VII, granite; VIII, granodiorite; IX, quartz diorite (tonalite).

volcanic rocks (fig. 8 ) changed from oligoclase $\left(\mathrm{An}_{24-31}\right)$ to albite $\left(A n_{10-13}\right)$. Inside the shear zone the medium-grained plagioclase phenocrysts have essentially equivalent compositions to the recrystallized $\mathrm{M}_{2}$ matrix plagioclase, suggesting that the larger crystals equilibrated with the matrix during $\mathrm{D}_{2}$ shearing.

A similar shift in plagioclase composition is recorded in the granodioritic rocks. Outside the shear zone (unit $\mathrm{Xg}$, fig. 2) the cores of the plagioclase phenocrysts are dominantly andesine $\left(\mathrm{An}_{27-40}\right)$ with rims of oligoclase $\left(\mathrm{An}_{17}\right)$. Inside the shear zone (unit Xgn, fig. 2), however, the composition becomes distinctly more albitic in the phenocryst cores $\left(\mathrm{An}_{16-22}\right)$, rims $\left(\mathrm{An}_{23-14}\right)$, and within the recrystallized fine-grained matrix $\left(\mathrm{An}_{16-22}\right)$, again indicating that the plagioclase reequilibrated to more albitic compositions as a result of shear-induced $\mathrm{M}_{2}$ recrystallization.

\section{GEOBAROMETRY}

The mineral assemblages of the rocks within the Mountain shear zone are simple, and, therefore, allow application of only one geobarometer (table 3). Recently, Hammerstrom and Zen (1986) presented an empirical geobarometer in which they calibrated the aluminum content of hornblende observed in calc-alkaline plutons as a function of depth of crystallization (pressure). They estimated pressure from the metamorphic mineral assemblages of the associated country rocks. Hammerstrom and Zen (1986)

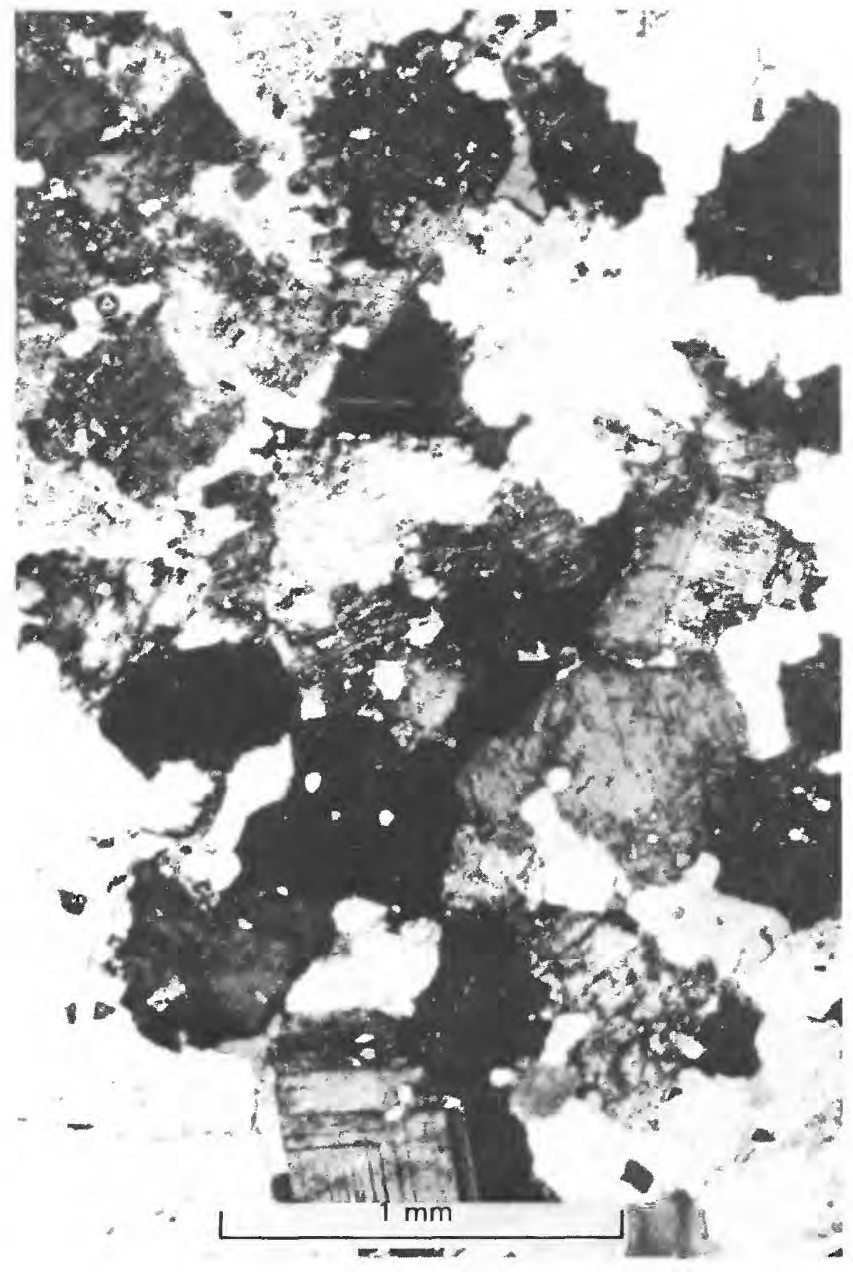

Figure 4. Photograph showing mosaic texture of quartz and feldspar in a granodiorite (129-85) inside the shear zone.

noted that the ratio of total $\mathrm{Al}\left(\mathrm{Al}^{\mathrm{t}}\right)$ to tetrahedral $\mathrm{Al}\left({ }^{\mathrm{IV}} \mathrm{Al}\right)$ in hornblende varies linearly, and that the $\mathrm{Al}^{\mathrm{t}}$ content is principally a function of pressure. Subsequent work by Hollister and others (1987) and Rutter and others (1989) has verified the hornblende geobarometer for use in calcalkaline plutonic rocks. Hollister and others (1989) independently confirmed the approach of Hammerstrom and Zen (1986) with additional data for hornblendes from calc-alkalic plutons from nine localities in the Central Gneiss Complex of British Columbia. They refined the equation for determining pressure, which resulted in decreasing the estimated error from \pm 3 kbar to $\pm 1 \mathrm{kbar}$. Rutter and others (1989) experimentally calibrated the geobarometer at higher pressures $(10 \mathrm{kbar})$ and confirmed its application to specific multimineral assemblages in which hornblende is in equilibrium with plagioclase, biotite, potassium feldspar, quartz, sphene, and magnetite or ilmenitetepidote. These phases are present in the granodiorite both inside and outside the Mountain shear zone.

Microprobe data and calculated pressures for hornblende from the granodiorite and metamorphosed basalt inside and outside the Mountain shear zone are presented in 


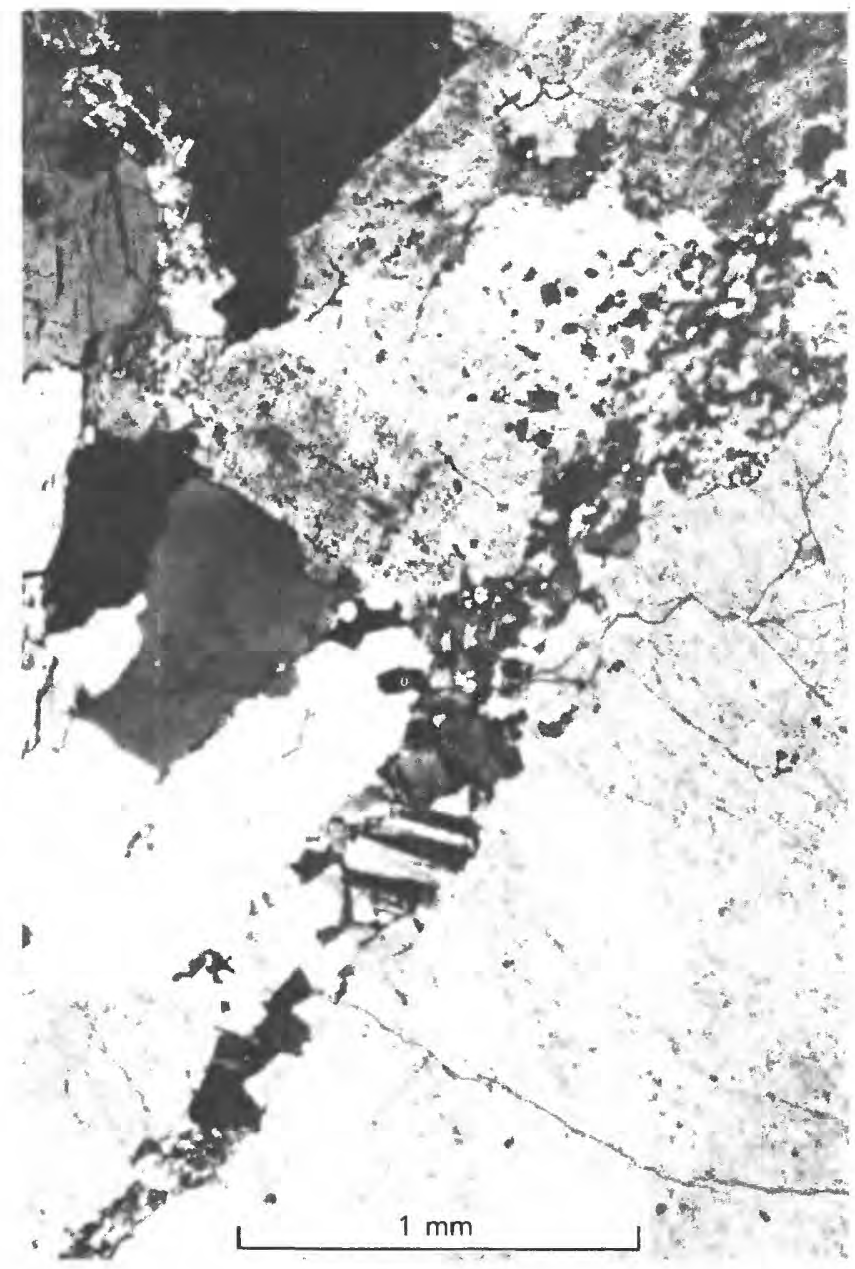

Figure 5. Photograph showing a small $M_{2}$ veinlet formed along margin of primary minerals in a granodiorite (165-85) outside the shear zone.

table 3 . The basalt does not strictly meet the multimineral assemblage criteria in that it lacks potassium feldspar. However, the hornblende compositions in the basalt are very similar to those in the granodiorite. Outside the shear zone the estimated equilibrium pressures using the method of Hollister and others (1987) for the primary $\mathrm{M}_{1}$ hornblende range from $4.0 \mathrm{kbar}$ for the granodiorite to $4.7 \mathrm{kbar}$ for the basalt, both of which are within the estimated error for the geobarometer of $\pm 1 \mathrm{kbar}$, suggesting that the geobarometer yields a reasonable estimate for the metabasalt. The secondary $\mathrm{M}_{2}$ hornblende in the basalt, which occurs along the rims of the $\mathbf{M}_{1}$ hornblende, yields an estimated pressure of $5.8 \mathrm{kbar}$. This is significantly higher than the $\mathrm{M}_{1}$ hornblende outside the zone.

Inside the shear zone the estimated pressure for the primary $\mathrm{M}_{1}$ hornblende is $4.3 \mathrm{kbar}$ for the basalt and 5.5 kbar for the granodiorite gneiss, similar to $M_{1}$ outside the shear zone. However, the calculated pressure of equilibration of the secondary $\mathrm{M}_{2}$ hornblende from the granodiorite gneiss is elevated (6.1 kbar), as is the $M_{2}$ hornblende from outside the zone. These data suggest that

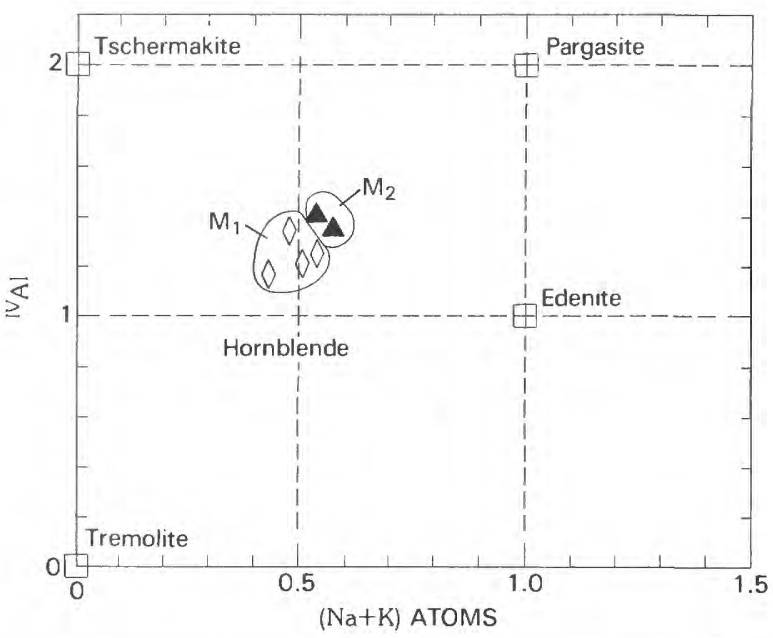

Figure 6. Hornblende composition data for rocks of the Mountain shear zone, northeastern Wisconsin. $M_{1}$ hornblende (diamond) contains less $\mathrm{Na}+\mathrm{K}$ and ${ }^{\mathrm{IV}} \mathrm{Al}$ compared to the younger $M_{2}$ hornblende (triangle). Data listed in table 3; analytical error approximately the symbol size.
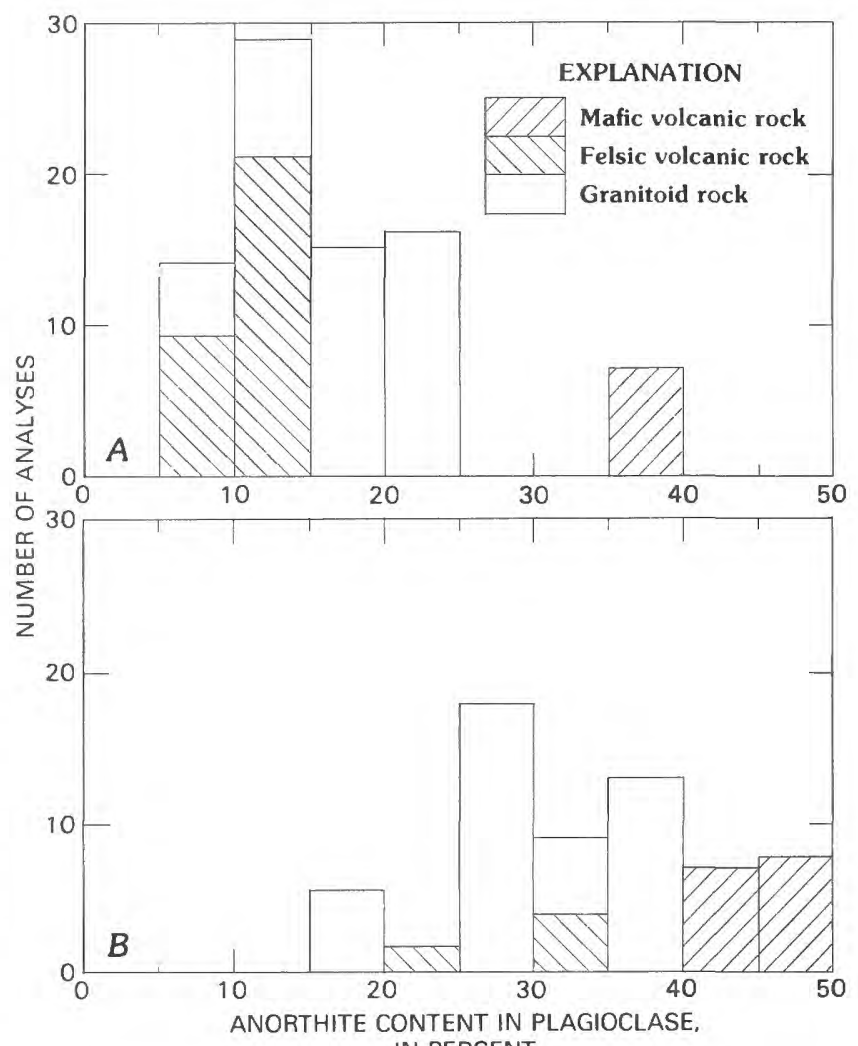

IN PERCENT

Figure 7. Histogram of plagioclase anorthite (An) content of rocks from $A$, inside, and $B$, outside the Mountain shear zone.

the $\mathrm{M}_{1}$ generation of hornblende equilibrated at similar pressures both inside and outside the shear zone at about $4.5 \pm 1 \mathrm{kbar}$. Subsequent deformation $\left(\mathrm{D}_{2}\right)$ associated with the development of the shear zone, as recorded in the $\mathbf{M}_{2}$ 
Table 3. Summary of microprobe data for hornblende and pressure estimates for rocks of the Mountain shear zone

\begin{tabular}{|c|c|c|c|c|c|c|}
\hline \multirow{4}{*}{ 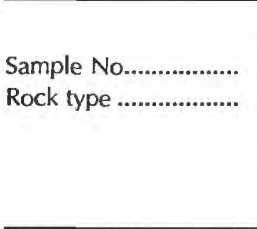 } & \multicolumn{3}{|c|}{ Outside shear zone } & \multicolumn{3}{|c|}{ Inside shear zone } \\
\hline & \multirow{2}{*}{\multicolumn{2}{|c|}{$\begin{array}{l}23-85 \\
\text { Basalt }\end{array}$}} & \multirow{3}{*}{$\begin{array}{c}\begin{array}{c}165-85 \\
\text { Grano- } \\
\text { diorite }\end{array} \\
\begin{array}{c}\text { Primary } \\
M_{1}\end{array}\end{array}$} & \multirow{3}{*}{$\begin{array}{c}20-85 \\
\text { Basalt } \\
\begin{array}{c}\text { Primary } \\
\mathrm{M}_{1}\end{array}\end{array}$} & \multirow{2}{*}{\multicolumn{2}{|c|}{$\begin{array}{c}129-85 \\
\text { Granodiorite } \\
\text { gneiss }\end{array}$}} \\
\hline & & & & & & \\
\hline & $\begin{array}{c}\text { Primary } \\
M_{1}\end{array}$ & $\begin{array}{c}\text { Secondary } \\
\mathrm{M}_{2}\end{array}$ & & & $\begin{array}{c}\text { Primary } \\
\mathrm{M}_{1}\end{array}$ & $\begin{array}{c}\text { Secondary } \\
\mathrm{M}_{2}\end{array}$ \\
\hline 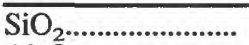 & 44.05 & 43.20 & 43.55 & 45.48 & 43.14 & 42.66 \\
\hline $\mathrm{Al}_{2} \mathrm{O}_{3} \ldots \ldots \ldots \ldots \ldots$ & 9.33 & 10.31 & 8.45 & 9.11 & 10.04 & 10.56 \\
\hline $\mathrm{FeO}$ & 19.95 & 20.07 & 20.30 & 16.78 & 22.49 & 22.79 \\
\hline MgO....................... & 8.68 & 8.16 & 8.40 & 11.04 & 7.34 & 7.02 \\
\hline $\mathrm{CaO}$ & 11.62 & 11.80 & 11.24 & 11.93 & 11.49 & 11.65 \\
\hline $\mathrm{Na}_{2} \mathrm{O}$ & 1.15 & 1.19 & 1.01 & 1.06 & 0.90 & 1.00 \\
\hline $\mathrm{K}_{2} \mathrm{O}$ & 0.98 & 1.10 & 1.01 & 0.64 & 1.06 & 1.18 \\
\hline $\mathrm{TiO}_{2} \ldots \ldots \ldots \ldots \ldots$ & 0.86 & 0.81 & 1.15 & 0.59 & 0.52 & 0.54 \\
\hline $\mathrm{MnO}$ & 0.40 & 0.38 & 0.68 & 0.48 & 0.49 & 0.52 \\
\hline Total (wt. pct.) & $\overline{97.02}$ & 97.02 & 95.79 & $\overline{97.11}$ & 97.66 & 97.92 \\
\hline No. analyses.......... & 6 & 6 & 3 & 10 & 6 & 7 \\
\hline \multicolumn{7}{|c|}{ Number of cations on the basis of 23 oxygens } \\
\hline ............... & 6.752 & 6.641 & 6.790 & 6.834 & 6.659 & 6.586 \\
\hline${ }^{\text {IV }} \mathrm{Al} \ldots . . . . . . . .$. & 1.248 & 1.359 & 1.210 & 1.166 & 1.341 & 1.414 \\
\hline $\mathrm{Al} \mathrm{VI} \ldots$ & 0.438 & 0.509 & 0.343 & 0.448 & 0.486 & 0.508 \\
\hline $\mathrm{Fe}^{+2} \ldots \ldots \ldots \ldots \ldots$ & 2.558 & 2.580 & 2.647 & 2.109 & 2.903 & 2.943 \\
\hline 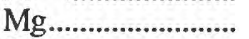 & 1.983 & 1.869 & 1.952 & 2.472 & 1.689 & 1.615 \\
\hline 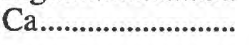 & 1.909 & 1.944 & 1.878 & 1.921 & 1.901 & 1.927 \\
\hline $\mathrm{Na} .$. & 0.342 & 0.355 & 0.305 & 0.309 & 0.269 & 0.299 \\
\hline $\mathrm{K} \ldots \ldots$ & 0.192 & 0.216 & 0.201 & 0.123 & 0.209 & 0.232 \\
\hline Ti....... & 0.099 & 0.094 & 0.135 & 0.067 & 0.060 & 0.063 \\
\hline 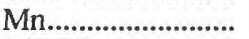 & 0.052 & 0.049 & 0.090 & 0.061 & 0.064 & 0.068 \\
\hline Al total..................... & 1.686 & 1.868 & 1.553 & 1.614 & 1.827 & 1.922 \\
\hline \multicolumn{7}{|c|}{ Pressure estimates (kbar) } \\
\hline $\begin{array}{l}\text { Hammerstrom } \\
\text { and Zen (1986) } \\
\text { (error } \pm 3 \text { kbar) }\end{array}$ & 4.6 & 5.5 & 3.9 & 4.2 & 5.3 & 5.7 \\
\hline $\begin{array}{l}\text { Hollister and } \\
\text { others (1987) } \\
\text { (error } \pm 1 \text { kbar) }\end{array}$ & 4.7 & 5.8 & 4.0 & 4.3 & 5.5 & 6.1 \\
\hline
\end{tabular}

hornblende, occurred at elevated pressures of approximately $6.0 \pm 1 \mathrm{kbar}$. Therefore, the dynamic recrystallization recorded in the shear zone was accompanied by a relative increase of approximately $1.5 \mathrm{kbar}$ pressure.

\section{GEOTHERMOMETRY}

Garnet-biotite geothermometry was applied to measure the thermal peaks of the $M_{1}$ and $M_{2}$ mineral assemblages, whereas a two-feldspar geothermometer was used to unravel the effects on low-temperature subsolidus recrystallization (post- $\mathrm{M}_{2}$ ) observed in the Mountain shear zone. The garnet-biotite geothermometers utilize the $\mathrm{Mg}:(\mathrm{Fe}-\mathrm{Mg} \pm \mathrm{Mn})$ ratio of coexisting garnet and biotite, and, therefore, the calculated temperatures should be internally consistent, allowing a comparison of the relative temperatures calculated for the $M_{1}$ and $M_{2}$ mineral assemblages. Although rare, garnet does coexist in textural equilibrium with biotite in the metamorphosed felsic volcanic rocks (unit Xwf, fig. 2) outside the shear zone (fig. 9) (samples 32-85 and 32B-85; tables 1 and 5). An extensive effort was made to find garnet within the shear zone; however, it is not present in the felsic volcanic rock (table 1). Garnet was noted in only one sample inside the shear zone, which was granodiorite gneiss (46-85). The garnet is an $\mathrm{M}_{1}$ metamorphic mineral, crosscutting the original igneous minerals (fig. 10). The garnet in this sample is compositionally zoned, having a more Fe-rich overgrowth $\operatorname{rim}\left(\mathrm{M}_{2}\right.$-stage).

The calculated temperatures using the biotite-garnet geothermometer of Ferry and Spear (1978), Hodges and Spear (1982), and Perchuck and Lavrent'eva (1983) are listed in table 5. These temperatures assume a pressure of $4.5 \mathrm{kbar}$ for the $\mathrm{M}_{1}$ metamorphism (garnet cores) and 6.0 kbar for the $\mathrm{M}_{2}$ metamorphism (garnet rims) as calculated from the hornblende geobarometer (table 3). The effect of pressure variation on the temperature calculations is 


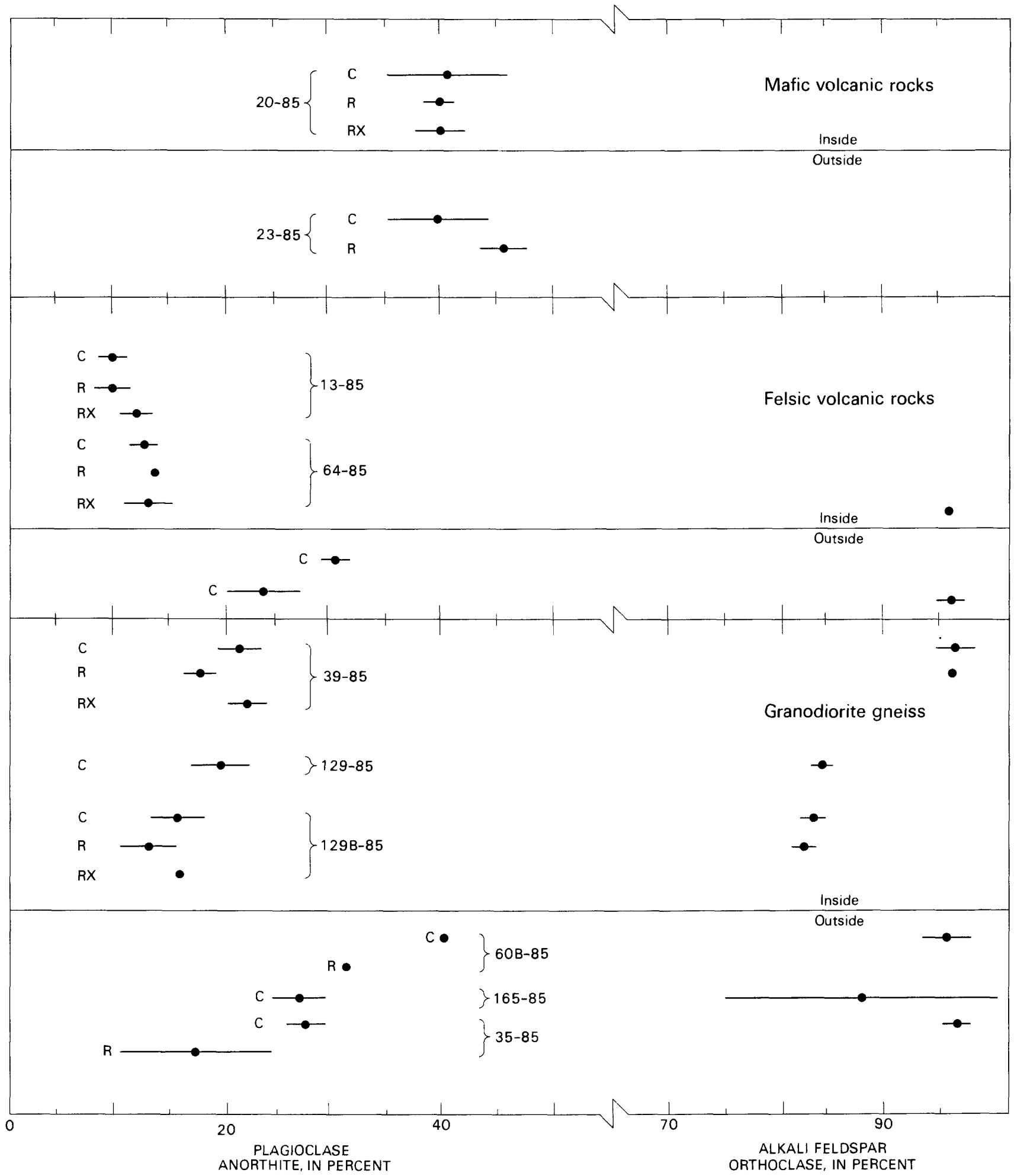

Figure 8. Plot of plagioclase anorthite (An) and alkali feldspar orthoclase (Or) content for rocks of various bulk compositions from inside and outside the Mountain shear zone. Error bars are one standard deviation from the mean (dot) for a sample. C, core; $R$, rim; $R X$, recrystallized $M_{2}$ feldspar.

minimal $\left(3^{\circ} \mathrm{C} / \mathrm{kbar}\right.$ using Hodges and Spear, 1982), which implies that any error in the calculated pressure is negligible when comparing the relative temperature variation.
The Ferry and Spear (1978) geothermometer yields an estimated temperature of $595{ }^{\circ} \mathrm{C}$ for $\mathrm{M}_{1}$ metamorphism (4.5 kbar) and $591{ }^{\circ} \mathrm{C}$ for $\mathrm{M}_{2}$ metamorphism (6.0 kbar) for 
Table 4. Summary of mean and standard deviation for feldspar microprobe data and temperature estimates using the two-feldspar geothermometer of Haselton and others (1983) for rocks in the Mountain shear zone area

[(No.), number of analyses; blank, not determined]

\begin{tabular}{|c|c|c|c|c|c|c|c|}
\hline & & \multirow[t]{2}{*}{ (No.) } & \multirow[t]{2}{*}{ An } & \multirow[t]{2}{*}{$\mathrm{Ab}$} & \multirow[t]{2}{*}{ Or } & \multicolumn{2}{|c|}{$\mathrm{T}\left({ }^{\circ} \mathrm{C}\right)$} \\
\hline & & & & & & $4.5 \mathrm{kbar}$ & $6.0 \mathrm{kbar}$ \\
\hline \multicolumn{8}{|c|}{ Outside the shear zone } \\
\hline \multicolumn{8}{|l|}{ 23-85 Basalt: } \\
\hline \multirow[t]{2}{*}{ Plagioclase } & Core & (7) & $40.3 \pm 4.6$ & $59.2 \pm 4.6$ & $0.4 \pm 0.1$ & & \\
\hline & Rim & $(10)$ & $46.1 \pm 1.8$ & $52.9 \pm 2.0$ & $1.0 \pm 1.0$ & & \\
\hline \multicolumn{8}{|c|}{ 32-85 Biotite schist (felsic metavolcanic): } \\
\hline Plagioclase & Core & (2) & $24.2 \pm 4.0$ & $74.8 \pm 2.7$ & $1.0 \pm 0.3$ & 297 & 312 \\
\hline Alkali-feldspar & Core & (3) & $0.0 \pm 0.0$ & $3.5 \pm 1.0$ & $96.5 \pm 1.1$ & & \\
\hline \multicolumn{8}{|c|}{ 32B-85 Biotite schist (felsic metavolcanic): } \\
\hline Plagioclase & Core & (4) & $31.3 \pm 1.7$ & $68.3 \pm 2.9$ & $3.8 \pm 0.9$ & & \\
\hline \multicolumn{8}{|c|}{ 35-85 Granodiorite porphyry: } \\
\hline \multirow[t]{2}{*}{ Plagioclase } & Core & (9) & $27.1 \pm 2.0$ & $72.2 \pm 2.0$ & $0.6 \pm 0.4$ & 310 & 325 \\
\hline & $\operatorname{Rim}$ & (3) & $17.5 \pm 7.6$ & $69.5 \pm 4.6$ & $13.0 \pm 9.2$ & 278 & 293 \\
\hline \multirow[t]{2}{*}{ Alkali-feldspar } & Core & (5) & $0.1 \pm 0.2$ & $3.7 \pm 0.3$ & $96.1 \pm 0.9$ & & \\
\hline & $\operatorname{Rim}$ & (1) & 1.3 & 3.0 & 95.7 & & \\
\hline \multicolumn{8}{|c|}{ 60B-85 Granodiorite: } \\
\hline Plagioclase & Core & (7) & $39.9 \pm 1.2$ & $58.2 \pm 1.1$ & $1.9 \pm 0.3$ & 420 & 439 \\
\hline Alkali-feldspar & Core & (6) & 0.0 & $6.2 \pm 2.4$ & $93.8 \pm 2.4$ & & \\
\hline \multicolumn{8}{|l|}{ Myrmekite } \\
\hline Plagioclase & Host & (4) & $26.1 \pm 2.0$ & $73.5 \pm 0.8$ & $0.4 \pm 0.1$ & 340 & 356 \\
\hline Alkali-feldspar & Bleb & (1) & 0.2 & 4.8 & 95.0 & & \\
\hline \multicolumn{8}{|c|}{ Intergranular recrystallized feldspar (with sericite alteration): } \\
\hline \multirow[t]{2}{*}{ Plagioclase } & Host & (5) & $31.6 \pm 0.2$ & $67.7 \pm 3.6$ & $0.6 \pm 0.2$ & & \\
\hline & New & $(6)$ & $36.5 \pm 1.8$ & $62.9 \pm 1.6$ & $0.6 \pm 0.1$ & & \\
\hline \multicolumn{8}{|c|}{ 165-85 Granodiorite: } \\
\hline Plagioclase & Core & (5) & $26.7 \pm 2.3$ & $83.6 \pm 1.6$ & $0.9 \pm 0.1$ & 441 & 458 \\
\hline Alkali-feldspar & Core & (3) & $1.2 \pm 1.0$ & $11.0 \pm 5.7$ & $87.8 \pm 13.8$ & & \\
\hline
\end{tabular}

dacite outside the shear zone. These temperatures are identical within the estimated error of the technique $\left( \pm 50{ }^{\circ} \mathrm{C}\right)$. Inside the shear zone, the estimated $\mathrm{M}_{1}$ temperature is relatively elevated to $645^{\circ} \mathrm{C}$, whereas the $\mathrm{M}_{2}$ temperature of $612^{\circ} \mathrm{C}$ (at $6.0 \mathrm{kbar}$ ) was essentially the same as that recorded outside the shear zone (table 5).

The Ferry and Spear (1978) geothermometer is based on ideal solid solution model for Fe-Mg cation exchange between garnet and biotite. Hodges and Spear (1982) recalibrated the geothermometer by incorporating manganese cation exchange between garnet and biotite and calcium exchange with plagioclase. This method yields temperature estimates outside the shear zone of about 610-615 ${ }^{\circ} \mathrm{C}$ for $\mathrm{M}_{1}$ and a slightly lower $601{ }^{\circ} \mathrm{C}$ for $\mathrm{M}_{2}$, all of which are within the estimated error of $\pm 50{ }^{\circ} \mathrm{C}$ for the technique. However, inside the shear zone the calculated temperatures are elevated to $661{ }^{\circ} \mathrm{C}$ for $\mathrm{M}_{1}$ and $654^{\circ} \mathrm{C}$ for $\mathrm{M}_{2}$.

Perchuck and Lavrent'eva (1983) presented another geothermometer that is based on the $\mathrm{Fe}-\mathrm{Mg}-\mathrm{Mn}$ cation exchange between garnet and biotite. In a recent review, Chipera and Perkins (1988) compared garnet-biotite geothermometers and suggested that the Perchuck and Lavrent'eva (1983) method yields the most precise and accurate results. However, as Indares and Martignole (1985) noted, the temperatures estimated from the Perchuck and Lavrent'eva (1983) geothermometer generally are lower for garnet with elevated manganese content. Outside the shear zone, the manganese content of the garnet is relatively low (about 3.5 wt. percent; table 5), and temperatures 
Table 4. Summary of mean and standard deviation for feldspar microprobe data and temperature estimates using the two-feldspar geothermometer of Haselton and others (1983) for rocks in the Mountain shear zone area-Continued

[(No.), number of analyses; blank, not determined]

\begin{tabular}{|c|c|c|c|c|c|c|c|}
\hline & & \multirow[t]{2}{*}{ (No.) } & \multirow[t]{2}{*}{ An } & \multirow[t]{2}{*}{$\mathrm{Ab}$} & \multirow[t]{2}{*}{ Or } & \multicolumn{2}{|c|}{$\mathrm{T}\left({ }^{\circ} \mathrm{C}\right)$} \\
\hline & & & & & & 4.5 kbar & $6.0 \mathrm{kbar}$ \\
\hline \multicolumn{8}{|c|}{ Inside the shear zone } \\
\hline \multicolumn{8}{|l|}{ 20-85 Basalt: } \\
\hline \multirow[t]{3}{*}{ Plagioclase } & Core & (7) & $38.1 \pm 6.2$ & $60.8 \pm 5.6$ & $1.1 \pm 1.0$ & & \\
\hline & Rim & & $37.3 \pm 0.9$ & $61.8 \pm 0.8$ & $0.9 \pm 0.5$ & & \\
\hline & Groundmass & & $37.6 \pm 1.7$ & $61.8 \pm 1.6$ & $0.6 \pm 0.1$ & & \\
\hline \multicolumn{8}{|c|}{ 13-85 Biotite schist (felsic volcanic): } \\
\hline \multirow[t]{3}{*}{ Plagioclase } & Core & $(5)$ & $9.8 \pm 1.2$ & $89.3 \pm 1.9$ & $0.9 \pm 0.5$ & & \\
\hline & $\operatorname{Rim}$ & (4) & $9.9 \pm 1.4$ & $87.8 \pm 3.9$ & $2.2 \pm 2.0$ & & \\
\hline & Groundmass & (5) & $11.8 \pm 1.1$ & $87.2 \pm 1.0$ & $1.0 \pm 0.4$ & & \\
\hline \multicolumn{8}{|c|}{ 64-85 Felsic metavolcanic: } \\
\hline \multirow[t]{3}{*}{ Plagioclase } & Core & (8) & $12.6 \pm 1.1$ & $83.6 \pm 5.4$ & $3.8 \pm 4.8$ & 268 & 282 \\
\hline & Rim & (3) & $13.8 \pm 0.5$ & $85.1 \pm 2.1$ & $1.1 \pm 1.1$ & 266 & 280 \\
\hline & Groundmass & (5) & $13.1 \pm 2.0$ & $85.2 \pm 1.5$ & $2.8 \pm 2.3$ & 266 & 280 \\
\hline Alkali-feldspar & Groundmass & (4) & $0.3 \pm 0.2$ & $3.3 \pm 0.3$ & $96.4 \pm 1.1$ & & \\
\hline \multicolumn{8}{|c|}{ 39-85 Granodiorite gneiss: } \\
\hline \multirow[t]{3}{*}{ Plagioclase } & Core & (6) & $21.5 \pm 2.0$ & $75.9 \pm 1.3$ & $2.5 \pm 2.0$ & 294 & 308 \\
\hline & $\operatorname{Rim}$ & (3) & $17.8 \pm 1.4$ & $76.1 \pm 5.5$ & $6.1 \pm 5.0$ & 293 & 307 \\
\hline & Groundmass & (2) & $22.0 \pm 1.3$ & $73.0 \pm 1.5$ & $4.9 \pm 0.7$ & 306 & 321 \\
\hline \multirow{2}{*}{ Alkali-feldspar } & Core & $(10)$ & $0.2 \pm 0.1$ & $3.5 \pm 1.0$ & $96.4 \pm 1.5$ & & \\
\hline & Groundmss & $(2)$ & $0.1 \pm 0.01$ & $3.7 \pm 0.4$ & $96.2 \pm 0.5$ & & \\
\hline \multicolumn{8}{|c|}{ 129-85 Granite gneiss: } \\
\hline \multirow[t]{2}{*}{ Plagioclase } & Core & (5) & $20.1 \pm 2.7$ & $79.2 \pm 2.0$ & $0.7 \pm 0.2$ & 469 & 487 \\
\hline & $\operatorname{Rim}$ & (3) & $22.8 \pm 2.7$ & $76.5 \pm 2.2$ & $0.6 \pm 0.1$ & 554 & 574 \\
\hline \multirow[t]{2}{*}{ Alkali-feldspar } & Core & (4) & $2.8 \pm 2.0$ & $13.3 \pm 6.6$ & $83.9 \pm 10.5$ & & \\
\hline & Groundmass & (2) & $1.0 \pm 0.2$ & $16.6 \pm 0.8$ & $82.4 \pm 0.8$ & & \\
\hline \multicolumn{8}{|c|}{ 129B-85 Granite gneiss: } \\
\hline \multirow[t]{3}{*}{ Plagioclase } & Core & (7) & $15.8 \pm 2.9$ & $83.6 \pm 2.0$ & $0.6 \pm 0.5$ & 443 & 460 \\
\hline & $\operatorname{Rim}$ & (8) & $13.5 \pm 2.7$ & $83.5 \pm 3.7$ & $3.0 \pm 3.1$ & 513 & 532 \\
\hline & Groundmass & (5) & $16.4 \pm 0.4$ & $82.8 \pm 1.2$ & $0.8 \pm 0.4$ & 519 & 538 \\
\hline \multirow[t]{2}{*}{ Alkali-feldspar } & Core & (4) & $3.3 \pm 1.0$ & $13.3 \pm 6.0$ & $83.4 \pm 0.8$ & & \\
\hline & Groundmass & $(2)$ & $1.0 \pm 0.2$ & $16.6 \pm 1.3$ & $82.4 \pm 0.8$ & & \\
\hline \multicolumn{8}{|c|}{ Crosscutting the shear zone } \\
\hline \multicolumn{8}{|c|}{ 147-85 Hines Quartz Diorite: } \\
\hline \multirow[t]{2}{*}{ Plagioclase } & Core & (5) & $42.3 \pm 0.7$ & $57.1 \pm 0.4$ & $0.3 \pm 0.1$ & & \\
\hline & Rim & (5) & $41.5 \pm 2.0$ & $58.0 \pm 1.1$ & $0.5 \pm 0.5$ & & \\
\hline
\end{tabular}

calculated are similar to those of the other two geothermometers. The estimated temperatures for $\mathrm{M}_{1}$ of about $590{ }^{\circ} \mathrm{C}$ and of about $576^{\circ} \mathrm{C}$ for $\mathrm{M}_{2}$ metamorphism are essentially equivalent to those calculated by the other geothermometers (table 5). However, inside the shear zone the garnet has appreciable $\mathrm{Mn}$ content (about 11 wt. percent; table 5) and the temperatures calculated for both $\mathrm{M}_{1}\left(565^{\circ} \mathrm{C}\right)$ and for $\mathrm{M}_{2}$ $\left(543{ }^{\circ} \mathrm{C}\right.$ ) are lower. The calculated $\mathrm{M}_{2}$ temperature is approximately $100^{\circ} \mathrm{C}$ cooler than that estimated by either the Ferry and Spear (1978) or the Hodges and Spear (1983) method and results from the effect in the calculation of elevated Mn content in the garnet.

Two-feldspar geothermometry indicates that the feldspars underwent subsolidus reequilibration during the waning stage of $D_{2}$ deformation. Plotted in figure 11 are calculated temperatures of feldspar equilibration using the 
Table 5. Summary microprobe data for garnet and biotite, and temperature estimates for rocks of the Mountain shear zone, northern Wisconsin

[Major oxides in weight percent; cation proportions in terms of number of oxygens; na, not analyzed]

\begin{tabular}{|c|c|c|c|c|c|c|c|c|}
\hline \multirow{4}{*}{$\begin{array}{l}\text { Sample No............... } \\
\text { Rock type................. }\end{array}$} & \multicolumn{5}{|c|}{ Outside shear zone } & \multirow{3}{*}{\multicolumn{3}{|c|}{$\begin{array}{l}\text { Inside shear zone } \\
\qquad 46-85 \\
\text { Granodiorite gneiss }\end{array}$}} \\
\hline & \multirow{2}{*}{\multicolumn{2}{|c|}{$\begin{array}{l}32-85 \\
\text { Dacite }\end{array}$}} & \multirow{2}{*}{\multicolumn{3}{|c|}{$\begin{array}{c}32 \mathrm{~B}-85 \\
\text { Dacite }\end{array}$}} & & & \\
\hline & & & & & & & & \\
\hline & $\begin{array}{l}\text { Garnet } \\
\text { core }\end{array}$ & Biotite & $\begin{array}{l}\text { Garnet } \\
\text { core }\end{array}$ & $\begin{array}{c}\text { Garnet } \\
\text { rim }\end{array}$ & Biotite & $\begin{array}{c}\text { Garnet } \\
\text { core }\end{array}$ & $\begin{array}{l}\text { Garnet } \\
\text { rim }\end{array}$ & Biotite \\
\hline $\mathrm{SiO}_{2} \ldots \ldots \ldots \ldots$ & 37.43 & 33.84 & 37.04 & 36.57 & 33.49 & 37.82 & 37.54 & 34.80 \\
\hline $\mathrm{Al}_{2} \mathrm{O}_{3} \ldots \ldots \ldots \ldots$ & 20.71 & 19.42 & 21.41 & 20.97 & 19.39 & 20.97 & 20.81 & 17.93 \\
\hline $\mathrm{FeO}$ & 34.39 & 22.86 & 35.19 & 35.12 & 23.00 & 25.60 & 26.61 & 20.86 \\
\hline 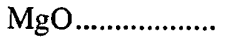 & 2.00 & 7.12 & 1.85 & 1.78 & 6.42 & 2.29 & 2.32 & 8.71 \\
\hline $\mathrm{CaO} \ldots \ldots \ldots \ldots \ldots$ & 1.71 & 0.04 & 1.24 & 1.38 & 0.03 & 1.37 & 1.08 & 0.05 \\
\hline $\mathrm{Na}_{2} \mathrm{O}$ & 0.06 & 0.14 & 0.07 & 0.06 & 0.10 & 0.01 & 0.02 & 0.11 \\
\hline $\mathrm{K}_{2} \mathrm{O} \ldots \ldots \ldots \ldots$ & na & 9.68 & na & na & 9.32 & na & na & 9.90 \\
\hline $\mathrm{TiO}_{2} \ldots \ldots \ldots \ldots \ldots$ & 0.06 & 1.54 & 0.05 & 0.05 & 1.59 & 0.09 & 0.05 & 1.90 \\
\hline $\mathrm{MnO}$ & 3.60 & 0.08 & 3.22 & 3.15 & 0.18 & 11.36 & 10.78 & 0.35 \\
\hline F & na & 0.31 & na & na & 0.24 & na & na & 0.33 \\
\hline \multirow[t]{2}{*}{$\mathrm{Cl}$} & na & 0.07 & na & na & 0.11 & na & na & 0.08 \\
\hline & & 95.10 & & & 93.87 & & & 95.02 \\
\hline$-\mathrm{O}=\mathrm{F} \ldots \ldots \ldots \ldots \ldots$ & & 0.13 & & & 0.10 & & & 0.14 \\
\hline$-\mathrm{O}=\mathrm{Cl}$ & & 0.02 & & & 0.02 & & & 0.02 \\
\hline Total.................. & 99.96 & 94.95 & 100.07 & 99.08 & 93.75 & 99.51 & 99.21 & 94.86 \\
\hline No. analyses ..... & 3 & 5 & 4 & 4 & 6 & 6 & 8 & 8 \\
\hline No. oxygens...... & 12 & 24 & 12 & 12 & 24 & 12 & 12 & 24 \\
\hline 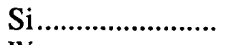 & 2.983 & 5.759 & 2.995 & 2.994 & 5.776 & 3.050 & 3.045 & 5.884 \\
\hline${ }^{\mathrm{IV}} \mathrm{Al}$ & 0.017 & 2.241 & 0.005 & 0.006 & 2.224 & 0.000 & 0.000 & 2.116 \\
\hline $\mathrm{Al}^{\mathrm{VI}} \ldots \ldots \ldots \ldots \ldots$ & 1.929 & 1.655 & 2.025 & 2.019 & 1.718 & 1.994 & 1.989 & 1.456 \\
\hline $\mathrm{Fe}$ & 2.293 & 3.253 & 2.380 & 2.404 & 3.317 & 1.727 & 1.805 & 2.950 \\
\hline $\mathrm{Mg}$ & 0.238 & 1.806 & 0.222 & 0.218 & 1.649 & 0.276 & 0.260 & 2.195 \\
\hline $\mathrm{Ca}$ & 0.146 & 0.007 & 0.107 & 0.121 & 0.005 & 0.118 & 0.094 & 0.009 \\
\hline $\mathrm{Na} . . . . . . . . . . . . . . . . . . . .$. & 0.010 & 0.047 & 0.012 & 0.009 & 0.035 & 0.002 & 0.003 & 0.037 \\
\hline $\mathrm{K}$ & na & 2.101 & na & na & 2.052 & na & na & 2.136 \\
\hline Ti.......................... & 0.006 & 0.197 & 0.003 & 0.003 & 0.206 & 0.005 & 0.003 & 0.242 \\
\hline 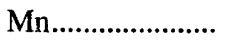 & 0.216 & 0.012 & 0.220 & 0.219 & 0.027 & 0.776 & 0.741 & 0.050 \\
\hline F & na & 0.166 & na & na & 0.133 & na & na & 0.177 \\
\hline $\mathrm{Cl} \ldots \ldots \ldots \ldots \ldots \ldots$ & na & 0.020 & na & na & 0.032 & na & na & 0.024 \\
\hline
\end{tabular}

Temperature estimates $\left({ }^{\circ} \mathrm{C}\right)$

Ferry and Spear

(1978):

$4.5 \mathrm{kbar}$

$6.0 \mathrm{kbar}$

594

600

Hodges and Spear (1982):

$4.5 \mathrm{kbar}$

$6.0 \mathrm{kbar}$

615

620

Perchuck and Lavrent'eva

(1983):

$4.5 \mathrm{kbar}$

$6.0 \mathrm{kbar}$

589

579

$595 \quad 585$

$601 \quad 591$

$610 \quad 601$

$616 \quad 606$

661

667

648

654 


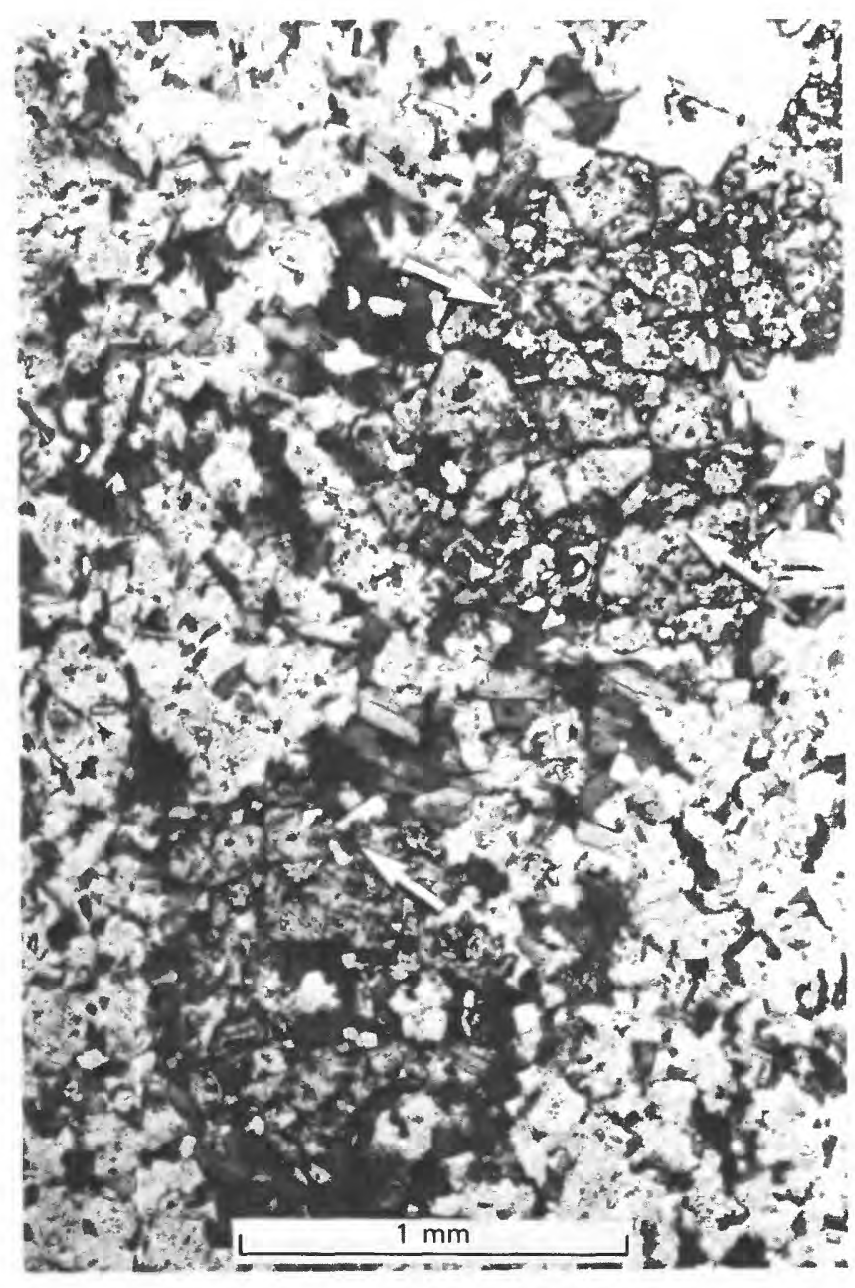

Figure 9. Photograph showing biotite and $\left(M_{1}\right)$ garnet (arrows) in a fine-grained felsic volcanic rock (32-85) outside the shear zone.

method of Haselton and others (1983). Although deformation and recrystallization were concentrated within the Mountain shear zone, each rock type sampled in the study area has fine-grained recrystallized $\mathrm{M}_{2}$ quartz-feldspar matrix material. Both inside and outside the shear zone, the temperatures of feldspar reequilibration range down to about $275^{\circ} \mathrm{C}$ (table 3), which is well below the peak $\mathrm{M}_{2}$ thermal conditions of about $650-670{ }^{\circ} \mathrm{C}$ recorded in the garnet-biotite data (table 5). The feldspar within the shear zone records a continuum in temperature from just slightly below the peak $\mathrm{M}_{2}\left(574^{\circ} \mathrm{C}\right.$ at $\left.6.0 \mathrm{kbar}\right)$ to the low similar to that observed outside the shear zone (about $293^{\circ} \mathrm{C}$ at 6.0 kbar). Outside the zone occurs a distinct temperature gap between the $M_{2}$ temperatures measured in garnet-biotite $\left(575-600^{\circ} \mathrm{C}\right)$ and those recorded in the feldspars $(275-450$ $\left.{ }^{\circ} \mathrm{C}\right)$.

The retrograde metamorphism may have caused reequilibration of the $\mathrm{Fe}-\mathrm{Mg}$ cation exchange within the biotite and garnet pairs analyzed to establish the peak $\mathrm{M}_{2}$

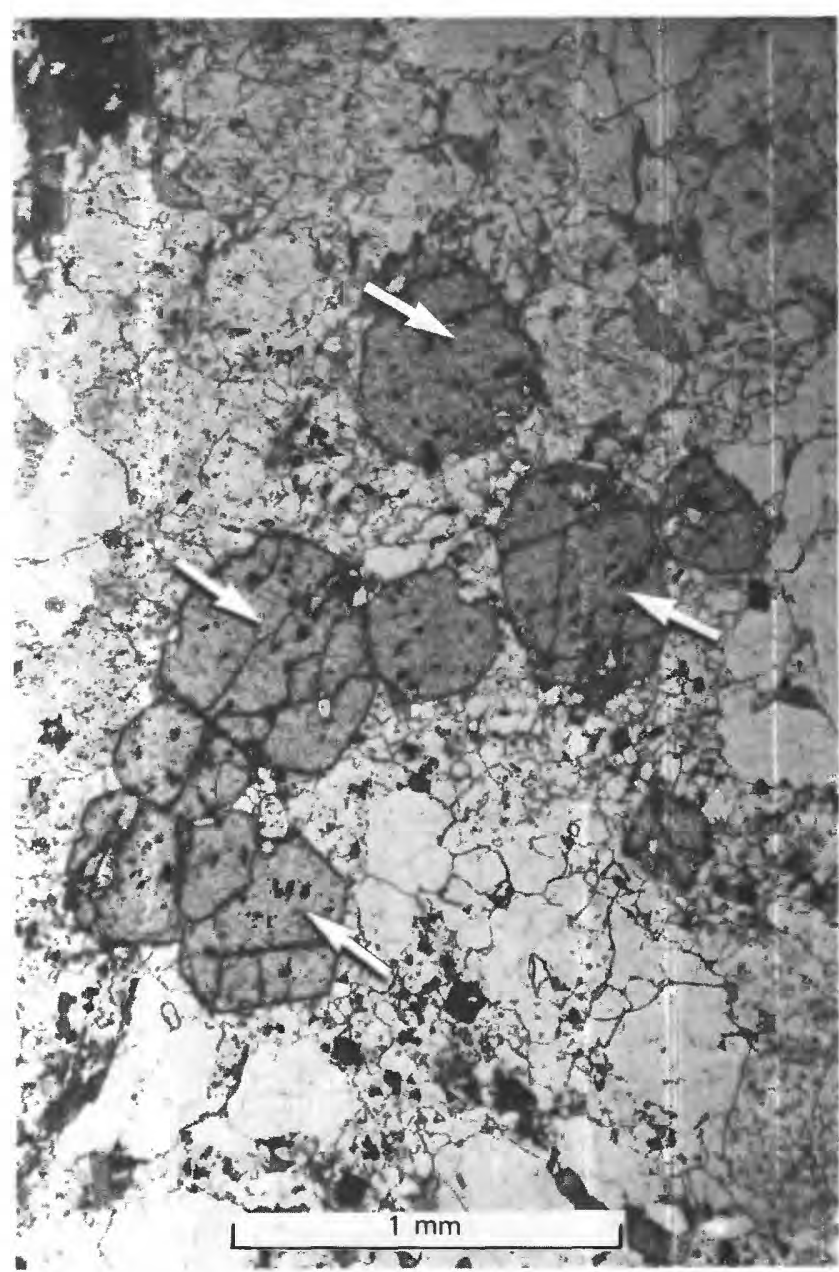

Figure 10. Photograph showing biotite and $\left(\mathrm{M}_{2}\right)$ garnet (arrows) in a granitoid rock (46-85) inside the shear zone.

metamorphic conditions. Therefore, the peak $\mathrm{M}_{2}$ conditions calculated are minimum estimates. The effects of the retrograde metamorphism should not drastically alter the relative peak $\mathrm{M}_{2}$ temperatures calculated, however, because the feldspar data indicate that the retrograde overprint is equivalent both inside and outside the shear zone.

\section{CONCLUSIONS}

Dynamic $\mathrm{M}_{2}$ recrystallization within the Mountain shear zone overprinted the regional $\mathrm{D}_{1}$ deformation fabric. Although the $D_{2}$ deformation was localized within the shear zone, the effects can be observed in rocks immediately adjacent to the south. Hornblende geobarometry indicates a relative increase in pressure of about $1.5 \mathrm{kbar}$ as a result of $\mathrm{D}_{2}$ deformation. Garnet-biotite geothermometry suggests a relative increase in temperature of as much as $60{ }^{\circ} \mathrm{C}$. However, the geothermometer developed by Perchuck and Lavrent'eva (1983), points to a possible slight relative 


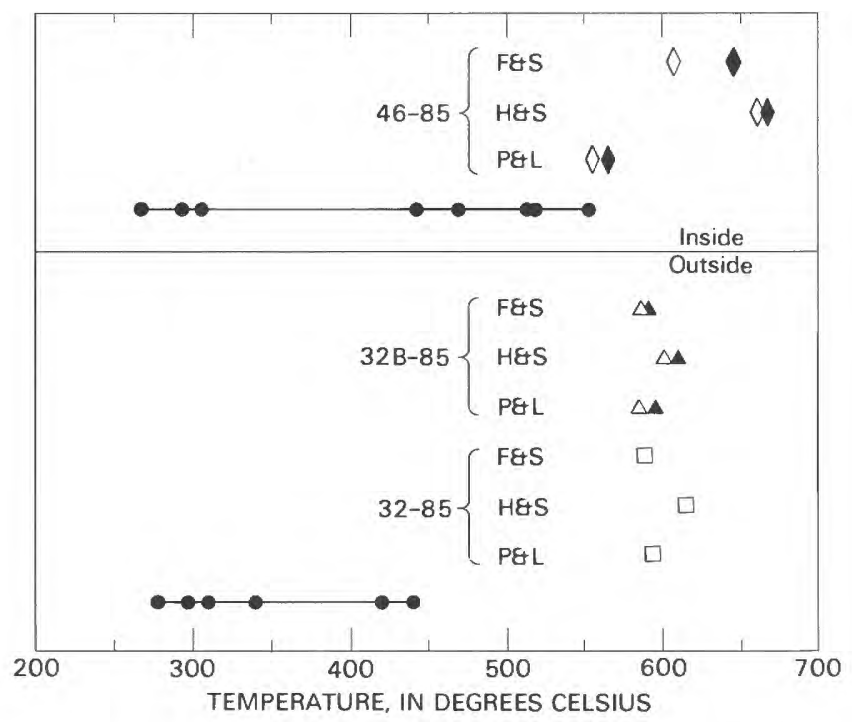

Figure 11. Comparison of the temperature estimates (at 4.5 kbar) from inside and outside the Mountain shear zone. Temperature estimates use the garnet-biotite geothermometers F\&S (Ferry and Spear, 1978), H\&S (Hodges and Spear, 1982), and P\&L (Perchuck and Lavrent'eva, 1983). Solid symbols, core compositions; open symbols, rim. Sample 46-85 (diamond), 32B-85 (triangle), and 32-85 (square). Temperature estimates using the two-feldspar geothermometer indicate (solid dots) that both inside and outside the shear zone, feldspar postpeak $\mathrm{M}_{2}$ reequilibrated down to about $275^{\circ} \mathrm{C}$.

decrease amounting to about $30{ }^{\circ} \mathrm{C}$ during $\mathrm{D}_{2}$. The lower estimated temperature of the Perchuck and Lavrent'eva (1983) geothermometer results in part from elevated manganese content in the garnet inside the shear zone. However, garnet is found only rarely both inside and outside the shear zone; therefore, these temperatures are only an estimate for the peak $\mathrm{M}_{2}$ thermal conditions. Reequilibration of the feldspars extended well below subsolidus temperatures. Only within the shear zone does a twofeldspar geothermometer yield temperatures similar to those of the garnet-biotite geothermometry.

\section{REFERENCES CITED}

Chipera, S.J., and Perkins, Dexter, 1988, Evaluation of biotitegarnet geothermometers-Application to the English River subprovince, Ontario: Contributions to Mineralogy and Petrology, v. 98 , p. $40-48$.

Ferry, J.M., and Spear, F.S., 1978, Experimental calibration of the partitioning of $\mathrm{Fe}$ and $\mathrm{Mg}$ between biotite and garnet: Contributions to Mineralogy and Petrology, v. 66, p. 113-117.

Hammerstrom, J.E., and Zen, E-an, 1986, Aluminum in hornblende-An empirical igneous geobarometer: American Mineralogist, v. 71, p. 1297-1313.

Haselton, H.T., Jr., Hovis, G.L., Hemingway, B.S., and Robie, R.A., 1983, Calorimetric investigations of the excess entropy of mixing in analbite-sanidine solid solutions-
Lack of evidence for $\mathrm{Na}, \mathrm{K}$ short-range order and implications for two-feldspar thermometry: American Mineralogist, v. 68 , p. 398-413.

Hodges, K.V., and Spear, F.S., 1982, Geothermometry, geobarometry and the $\mathrm{Al}_{2} \mathrm{O}_{3}$ triple point at Mt. Moosilauke, New Hampshire: American Mineralogist, v. 67, p. 1118-1134.

Hollister, L.S., Grissom, G.C., Peters, E.K., Stowell, H.H., and Sisson, V.B., 1987, Confirmation of the empirical correlation of $\mathrm{Al}$ in hornblende with pressure of solidification of calc-alkaline plutons: American Mineralogist, v. 72, p. 231-239.

Indares, A., and Martignole, J., 1985, Biotite-garnet geothermometry in the granulite facies-The influence of $\mathrm{Ti}$ and $\mathrm{Al}$ in biotite: American Mineralogist, v. 70, p. 272-278.

Jackson, L.L., Brown, F.W., and Neil, S.T., 1987, Major and minor elements requiring individual determination, classical whole rock analysis, and rapid rock analysis, in Baedecker, P.A., ed., Methods of geochemical analysis: U.S. Geological Survey Bulletin 1770, p. G1-G23.

Jackson, L.L., Taggart, J.E., and Foord, E.E., 1985, Quantitative determination of water in small material samples: Abstract, Pittsburgh Conference, New Orleans, La., p. 1191.

Lister, G.S., and Snoke, A.W., 1984, S-C mylonites: Journal of Structural Geology, v. 6, p. 617-638.

Peck, L.C., 1964, Systematic analysis of silicates: U.S. Geological Survey Bulletin 1170, 89 p.

Perchuck, L.L., and Lavrent'eva, I.V., 1983, Experimental investigations of exchange equilibria in the system cordieritegarnet-biotite, in Saxena, S.K., ed., Kinetics and equilibrium in mineral reactions: New York, Springer-Verlag, p. 199-239.

Rutter, M.J., Van der Laan, S.R., and Wyllie, P.J., 1989, Experimental data for a proposed igneous geobarometer-Aluminum in hornblende at $10 \mathrm{kbar}$ pressure: Geology, v. 17, p. 897-900.

Sims, P.K., 1987, Metallogeny of Archean and Proterozoic terranes in the Great Lakes region-A brief overview: U.S. Geological Survey Bulletin 1694-E, p. 55-80.

1989, Geologic map of Proterozoic rocks near Mountain, Oconto County, Wisconsin: U.S. Geological Survey Miscellaneous Investigations Series Map I-1903, scale $1: 24,000$.

Sims, P.K., Klasner, J.S., and Peterman, Z.E., 1990, The Mountain shear zone, northeastern Wisconsin-A discrete ductile deformation zone within the Early Proterozoic Penokean orogen: U.S. Geological Survey Bulletin 1904-A, 15 p.

Sims, P.K., Van Schmus, W.R., Schulz, K.J., and Peterman, Z.E., 1989, Tectono-stratigraphic evolution of the Early Proterozoic Wisconsin magmatic terranes of the Penokean orogen: Canadian Journal of Earth Sciences, v. 26, p. 2145-2158.

Taggart, J.E., Lindsay, J.R., Scott, B.A., Vivit, D.V., Bartel, A.J., and Stewart, K.C., 1987, Analysis of geologic materials by wavelength-dispersive $\mathrm{X}$-ray fluorescence spectrometry, in Baedecker, P.A., ed., Methods of geochemical analysis: U.S. Geological Survey Bulletin 1770, p. E1-E19.

Wise, D.U., and others, 1984, Fault-related rocks-Suggestions for terminology: Geology, v. 12, p. 391-394. 


\section{SELECTED SERIES OF U.S. GEOLOGICAL SURVEY PUBLICATIONS}

\section{Perlodicals}

Earthquakes \& Volcanoes (issued bimonthly).

Preliminary Determination of Epicenters (issued monthly).

\section{Technical Books and Reports}

Professional Papers are mainly comprehensive scientific reports of wide and lasting interest and importance to professional scientists and engineers. Included are reports on the results of resource studies and of topographic, hydrologic, and geologic investigations. They also include collections of related papers addressing different aspects of a single scientific topic.

Bulletins contain significant data and interpretations that are of lasting scientific interest but are generally more limited in scope or geographic coverage than Professional Papers. They include the results of resource studies and of geologic and topographic investigations; as well as collections of short papers related to a specific topic.

Water-Supply Papers are comprehensive reports that present significant interpretive results of hydrologic investigations of wide interest to professional geologists, hydrologists, and engineers. The series covers investigations in all phases of hydrology, including hydrogeology, availability of water, quality of water, and use of water.

Circulars present administrative information or important scientific information of wide popular interest in a format designed for distribution at no cost to the public. Information is usually of short-term interest.

Water-Resources Investigations Reports are papers of an interpretive nature made available to the public outside the formal USGS publications series. Copies are reproduced on request unlike formal USGS publications, and they are also available for public inspection at depositories indicated in USGS catalogs.

Open-File Reports include unpublished manuscript reports, maps, and other material that are made available for public consultation at depositories. They are a nonpermanent form of publication that may be cited in other publications as sources of information.

\section{Maps}

Geologic Quadrangle Maps are multicolor geologic maps on topographic bases in 71/2-or 15-minute quadrangle formats (scales mainly $1: 24,000$ or $1: 62,500$ ) showing bedrock, surficial, or engineering geology. Maps generally include brief texts; some maps include structure and columnar sections only.

Geophysical Investigations Maps are on topographic or planimetric bases at various scales; they show results of surveys using geophysical techniques, such as gravity, magnetic, seismic, or radioactivity, which reflect subsurface structures that are of economic or geologic significance. Many maps include correlations with the geology.

Miscellaneous Investigations Series Maps are on planimetric or topographic bases of regular and irregular areas at various scales; they present a wide variety of format and subject matter. The series also includes 7 1/2-minute quadrangle photogeologic maps on planimetric bases which show geology as interpreted from aerial photographs. Series also includes maps of Mars and the Moon.
Coal Investigations Maps are geologic maps on topographic or planimetric bases at various scales showing bedrock or surficial geology, stratigraphy, and structural relations in certain coal-resource areas.

Oil and Gas Investigations Charts show stratigraphic information for certain oil and gas fields and other areas having petroleum potential.

Miscellaneous Field Studies Maps are multicolor or black-andwhite maps on topographic or planimetric bases on quadrangle or irregular areas at various scales. Pre-1971 maps show bedrock geology in relation to specific mining or mineral-deposit problems; post-1971 maps are primarily black-and-white maps on various subjects such as environmental studies or wildemess mineral investigations.

Hydrologic Investigations Atlases are multicolored or black-andwhite maps on topographic or planimetric bases presenting a wide range of geohydrologic data of both regular and irregular areas; principal scale is $1: 24,000$ and regional studies are at $1: 250,000$ scale or smaller.

\section{Catalogs}

Permanent catalogs, as well as some others, giving comprehensive listings of U.S. Geological Survey publications are available under the conditions indicated below from the U.S. Geological Survey, Books and Open-File Reports Section, Federal Center, Box 25425, Denver, CO 80225. (See latest Price and Availability List.)

"Publications of the Geological Survey, 1879-1961" may be purchased by mail and over the counter in paperback book form and as a set of microfiche.

"Publications of the Geological Survey, 1962-1970" may be purchased by mail and over the counter in paperback book form and as a set of microfiche.

"Publications of the U.S. Geological Survey, 1971- 1981" may be purchased by mail and over the counter in paperback book form (two volumes, publications listing and index) and as a set of microfiche.

Supplements for $1982,1983,1984,1985,1986$, and for subsequent years since the last permanent catalog may be purchased by mail and over the counter in paperback book form.

State catalogs, "List of U.S. Geological Survey Geologic and Water-Supply Reports and Maps For (State)," may be purchased by mail and over the counter in paperback booklet form only

"Price and Availability List of U.S. Geological Survey Publications," issued annually, is available free of charge in paperback booklet form only.

Selected copies of a monthly catalog "New Publications of the U.S. Geological Survey" available free of charge by mail or may be obtained over the counter in paperback booklet form only. Those wishing a free subscription to the monthly catalog "New Publications of the U.S. Geological Survey" should write to the U.S. Geological Survey, 582 National Center, Reston, VA 22092.

Note.--Prices of Government publications listed in older catalogs, announcements, and publications may be incorrect. Therefore, the prices charged may differ from the prices in catalogs, announcements, and publications. 
